\title{
Rapid Evolution of the Visual System: A Cellular Assay of the Retina and Dorsal Lateral Geniculate Nucleus of the Spanish Wildcat and the Domestic Cat
}

\author{
Robert W. Williams, ${ }^{1}$ Carmen Cavada, ${ }^{2}$ and Fernando Reinoso-Suárez ${ }^{2}$ \\ 'Department of Anatomy and Neurobiology, College of Medicine, University of Tennessee, Memphis, Tennessee 38163 \\ and 'Departamento de Morfología, Facultad de Medicina, Universidad Autónoma de Madrid, 28029 Madrid, Spain
}

\begin{abstract}
The large Spanish wildcat, Felis silvestris tartessia, has retained features of the Pleistocene ancestor of the modern domestic cat, $F$. catus. To gauge the direction and magnitude of short-term evolutionary change in this lineage, we have compared the retina, the optic nerve, and the dorsal lateral geniculate nucleus (LGN) of Spanish wildcats and their domestic relatives. Retinas of the two species have the same area. However, densities of cone photoreceptors are higher in wildcat-over $100 \%$ higher in the area centralis-whereas rod densities are as high, or higher, in the domestic lineage. Densities of retinal ganglion cells are typically 20$100 \%$ higher across the wildcat retina, and the total ganglion cell population is nearly $\mathbf{7 0} \%$ higher than in the domestic cat. These differences are confined to the populations of beta and gamma retinal ganglion cells. In contrast, the population of alpha cells is almost precisely the same in both species. The wildcat LGN is much larger than that of the domestic cat and contains $50 \%$ more neurons. However, cell size does not differ appreciably in either the retina or LGN of these species. The differences in total numbers of ganglion cells and LGN neurons correspond neatly to the overall decline in brain size in the domestic lineage and to allometric predictions based on average species differences in body size. We suggest that an increase in the severity of naturally occurring cell death is the most plausible mechanism that can account for the rapid evolutionary reduction in cell populations in this feline lineage.
\end{abstract}

IKey words: brain size, allometry, rods and cones, retinal ganglion cell, optic nerve, lateral geniculate nucleus, cell death]

The tempo of mammalian brain evolution has been rapid. Twofold changes in brain weight have occurred over periods of 15 million years in several lineages, including that of humans (Edinger, 1948, 1966; Jerison, 1973, 1979; Radinsky, 1973, 1975, 1981; Eisenberg, 1981). Although this is an interesting

\footnotetext{
Reccived Apr. 14, 1992; revised July 13, 1992; accepted July 15, 1992.

This research was supported in part by Grant DGICYT PB88-0170 and a grant from the NIH. We are especially indebted to Mariano Sanz Pech and Antonio Pérez Alonso-Geta of the Institute for the Conservation of Nature, Madrid, Spain, for wildcat material. We thank Drs. Leo Chalupa, Andrea Elberger, and Douglas Frost for the generous use of material from their collections of domestic cat tissue, and Drs. Leo Chalupa, Robert Foehring, Dan Goldowitz, Todd Preuss, Anton Reiner, and Michael Rowe for critical comments on drafts of the manuscript.

Correspondence should be addressed to Dr. Robert Williams at the above address.

Copyright (C) 1993 Society for Neuroscience $0270-6474 / 93 / 130208-21 \$ 05.00 / 0$
}

and important topic, it has been difficult to study the process of brain evolution in any detail. Our approach has been to identify a pair of closely related living species, one from a highly conservative branch that has retained near identity with the ancestral species, and the other from a derived branch that has undergone rapid evolutionary change. The recent recognition that evolution and speciation can occur in short bursts separated by long interludes of stasis provides a sound theoretical basis for a search for such pairs (Schindewolf, 1950; Eldredge and Gould, 1972; Stanley, 1979; Gould and Eldredge, 1986).

A candidate pair among mammals is the wildcat, Felis silvestris, and the domestic cat, $F$. catus. Historical, biochemical, and genetic data point to a derivation of the domestic cat from the North African wildcat, $F$. silvestris lybica (Darwin, 1890; Clutton-Brock, 1981; Benveniste, 1985; Collier and O'Brien, 1985; Wayne et al., 1989). This small North African wildcat descended from a larger ancestor whose Pleistocene fossil record has been described carefully by Kurtén $(1965 a, b)$. These Pleistocene wildcats share a constellation of features-short premolar-canine diastema, large canine and carnassial teeth, and a low crowned fourth lower premolar - with the particular subspecies we have studied, $F$. silvestris tartessia (Kurtén, 1965a,b). In fact, the Spanish wildcat has more in common with wildcats living toward the end of the Würm glaciation, 15,000-20,000 years before present (BP) than with other extant $F$. silvestris subspecies (Table 1). For this reason, Kurten (1965b) concluded that the Spanish subspecies is an isolated relict of an ancient Mediterranean wildcat population that has survived with minimal change for over 20,000 years in a warm lberian refuge.

We decided that a comparison of this particular wildcat subspecies with the domestic cat could provide detailed insight into the range, rate, and direction of evolutionary change in brain structure. For example, we thought we would be able to determine whether the rapid decline in body size in the cat lineage has been associated with a matched decline in brain mass and, if so, whether this change has been brought about by a reduction in neuron number or an increase in cell packing density. We also thought it would be possible to determine whether numerical relations among interconnected parts of the brain have been conserved in this rapidly evolving mammalian lineage, and if so, then how precisely. Finally, we thought it might be possible to compare ontogenetic differences in these species and thereby expose developmental and cellular mechanisms that ultimately underlie phyletic change.

Taking advantage of the wealth of data on the structure of the primary visual system of domestic cats, we have begun with 
a quantitative analysis of populations of cells in the retina and the dorsal lateral geniculate nucleus (LGN) of the Spanish wildcat. In this analysis we make two explicit assumptions: first, that th? adult wildcats, which we have had the very rare opportunity to study, are representative of the Spanish subspecies; and second, that the Spanish wildcat is itself represcntative of, or at least similar to, the ancestral population of Pleistocene wildcats from which domestic cats ultimately trace their descent. The validity of these key assumptions is supported by data summarized in the next section (Table 1). From this vantage point, we attempt to assess structural changes in the primary visual system associated with approximately 25,000 years of natural selection at the close of the Pleistocene, followed by $3000-4000$ years of domestication.

\section{Materials and Methods}

We received two adult wildcats (Felis silvestris tartessia Miller), a male $(S 1)$ and a female $(S 2)$, from the Institute for the Conservation of Nature (ICONA), Spain. Both animals had been rescued from game traps in the Sierra Morena of south central Spain. The two thin but healthy animals had been held for several months in a large outdoor pen. Breeding was thought to have failed. Both animals had the coat color and pattern typical of wildcats and many domestic tabby cats (Haltenorth, 1953; Rodríguez de la Fuente, 1979). Each had four prominent dark streaks running down the neck, a single broad dark band running along the dorsal midline to the base of the tail, six to eight less distinct dark arched bands running from back to abdomen, and three to four dark rings around limbs and tails. Figure 26 in Haltenorth (1953) shows a specimen of the $F$. silvestris tartessia type at the Zoologische Staatssammlung (Munich, Germany) with a coat pattern almost indistinguishable from that of our animals. The ages of the two wildcats were unknown, but both appeared to be young adults. A single fetus was found in the female after her perfusion.

$F$. silvestris is not listed as an endangered or threatened species under the U.S. Endangered Species Act or the Convention for International Trade in Endangered Species of Wild Fauna and Flora (CITES, 1991). However, all Felidae except the domestic cat, $F$. catus, are listed in Appendix 2 of CITES and are subject to import and export regulations. The wildcat is protected by law in Spain. We complied with all conditions of the ICONA permit and all relevant CITES regulations.

Confirmation of the wildcat subspecies and the morphological similarity between Spanish wildcats and Pleistocene wildcats. The size and morphology of the teeth and jaws are among the most reliable criteria by which to identify species and subspecies of vertebrates (Kurtén, 1954; Carroll, 1988). Without resorting to statistical analysis, the dental measurements taken from our specimens conform closely to those of three F. silvestris tartessia specimens previously studied by Kurtén (1965a; Table 1). What is even more remarkable and significant is that our wildcats also do not differ appreciably from a sample of Pleistocene wildcats dated $\approx 15,000$ years before present (BP; late Main Würm). A relatively objective index of the degree of similarity or dissimilarity is provided by the $t$ value calculated for all 13 parameters (Table 1, far right). This more rigorous comparison demonstrates that our Spanish wildcats are remarkably similar to Late Main Würm wildcats $(t=0.64)$, but differ greatly from modern European wildcats $(t=7.11)$, from domestic cats, including a huge $9 \mathrm{~kg}$ domestic tabby cat $(t=4.76)$, and from a sizable sample of Neolithic $(7500 \mathrm{BP})$ wildcats $(t=2.41)$. The overall body size of our wildcats also overlaps measurements on $F$. silvestris tartessia provided by Haltenorth (1953, his Tables 2 and 4). In sum, the animals we have studied have been correctly classified as $F$. silvestris tartessia. They are certainly not feral domcstic cats, wild hybrids, or a different subspecies of $F$. silvestris. These data also provide a strong case that $F$. silvestris tartessia represents an isolated relict of a late Pleistocene wildcat population.

Sources of domestic cat material. Domestic cat tissue was obtained from our colonies in Madrid and the University of Tennessee, and from Drs. L. M. Chalupa, A. Elberger, and D. Frost. An extremely large domestic cat was provided to us by Dr. A. Tuberville to explore the upper limits in the size of the brain and dentary that might be expected among domestic cats. This huge young domestic cat weighed $9 \mathrm{~kg}$, was $61 \mathrm{~cm}$ from crown to rump, and had femurs that were $16.5 \mathrm{~cm}$ long.
Femurs of European wildcats are typically less than $13 \mathrm{~cm}$ long (Röhrs, 1955).

HRP injection procedure. We made injections of horseradish peroxidase (HRP) into the left dorsal lateral geniculate nucleus (LGN), left superior colliculus, and left pretectal region of the male wildcat $(S I)$. Similar unilateral $(n=1)$ and bilateral $(n=3)$ series of injections were made into normal domestic cats. Some of the domestic cat retinas have been described and illustrated in previous studies (Chalupa et al., 1984; Kirby and Chalupa, 1986). Animals initially received a single intramuscular dose of ketamine $(0.4 \mathrm{cc})$ and atropine $(0.2 \mathrm{cc})$ and were subsequently anesthetized with an intravenous injection of sodium pentobarbital $(30 \mathrm{mg} / \mathrm{kg})$. They were placed in a stereotaxic device and craniotomies were made over the approximate locations of the left superior colliculus, pretectum, and dorsal lateral geniculate nucleus. The boundaries of retinorecipient nuclei were mapped by recording multicellular visually evoked activity with a tungsten microelectrode. A series of 150-200 nl injections of 25\% HRP diluted in pure dimethyl sulfoxide (DMSO) were made along each penetration within the LGN (23 penetrations), pretectum (6 penetrations), and superior colliculus (10 penetrations) as described in Chalupa et al. (1984). The total volume of HRP delivered in a single penetration ranged from 200 to $600 \mathrm{nl}$.

Perfusion and dissection of the animals. All animals received an overdose of pentobarbital ( $200 \mathrm{mg}$ ) and were subsequently perfused through the hcart with phosphate-buffered saline $(0.1 \mathrm{~m}, \mathrm{pH} 7.3)$, followed by a mixture of $1.25 \%$ paraformaldehyde and $2.5 \%$ glutaraldehyde in phosphate buffer. We removed the cranial vault in one large intact piece, and the brain-including olfactory bulb, pituitary, and the entire medulla (Fig. 1) - the eyes, and segments of most cranial nerves were removed. We took retinas from the eyes and flattened them by making a set of radial cuts. The areas of flat-mounted retinas were measured before dehydration. We cleaned crania and dentaries in a $25 \%$ solution of bleach. Pelts of both wildcats were returned to ICONA.

Following the transcardial perfusion of wildcat $S 2$, an adult female that we had palpated on two previous occasions to be certain that she was not pregnant, we explored the abdominal cavity and found a single fetus. The fetus was immediately removed and fixed briefly by transcardial perfusion followed by prolonged immersion in fixative. Preservation of optic nerves proved to be surprisingly good, and given the value of this rare fetal wildcat material, we undertook a detailed analysis of both nerves using procedures identical to those described in a previous study on the optic nerves of domestic cat embryos (Williams et al., 1986).

Processing of retinas. A modification of the Hanker-Yates procedure (Perry and Linden, 1982; Chalupa et al., 1984) was used to demonstrate the presence of HRP within retinal ganglion cells in wildcat $S 1$ and normal domestic cat retinas. We stained retinas of the female wildcat with toluidine blue using the method described by Wong and Hughes (1987b). Additional domestic cat retinas were mounted between coverslips in glycerin and used for the analysis of the photoreceptor mosaic using methods summarized in Williams (1991).

Brain histology. Brains were hemisected in the sagittal plane. The left hemispheres were cut frozen at $50 \mu \mathrm{m}$ in the coronal plane. These frozen sections were collected and distributed in several series. The first and third series were stained with cresyl violet; the second series was in some cases reacted for HRP histochemistry using diaminobenzidine as the chromogen. Right hemispheres were embedded in celloidin and cut in either the coronal or the horizontal plane at $50 \mu \mathrm{m}$. For comparison, frozen and celloidin coronal sections from 11 domestic cats were examined.

Photoreceptor analysis. We measured the density of rods and cones along the horizontal meridian in the left retina of $S 1$ and two domestic cats. A $63 \times 1.25 \mathrm{NA}$ semiapochromatic objective with a very long working distance $(500 \mu \mathrm{m})$ was used to focus on the photoreceptor mosaic from either the vitreal or scleral side of the retina using differential interference contract (DIC) optics, a video overlay system, and semiautomatic image analysis software written for use with an Apple Macintosh computer (Fig. 2). A $50 \mathrm{~W}$ high-pressure mercury light source was used with or without narrow-band interference filters to obtain optimal contrast and resolution. Analog and digital video enhancement were used to improve the contrast of the photoreceptor mosaic as viewed on an RGB monitor. Rods and cones were counted in fields of $144 \mu \mathrm{m}^{2}$ and $1000 \mu \mathrm{m}^{2}$, respectively, using a video overlay setup (Wikler et al., 1990; Williams, 1991). Locations of sites in the retina were measured with reference to the center of the area centralis using linear encoders attached to the stage (Heidenhain Inc., LS 403 encoders; $0.2 \mu \mathrm{m}$ resolution; accuracy, $\pm 10 \mu \mathrm{m}$ over $50 \mathrm{~mm}$ ). 
Table 1. Size of teeth used to assess status of wildcats

\begin{tabular}{|c|c|c|c|c|c|c|}
\hline \multirow[b]{2}{*}{ Felis type } & & \multicolumn{2}{|l|}{$\underline{\mathrm{Ci}}$} & \multicolumn{3}{|l|}{$\mathbf{P}_{3}$} \\
\hline & & Length & Width & Length & Width & Height \\
\hline \multirow[t]{2}{*}{ Felis catus (Spanish sample) } & range & $4.5-5.6$ & $3.2-4.1$ & $4.7-5.3$ & $2.3-2.4$ & $3.5-4.0$ \\
\hline & mean $(n=3)$ & 5.00 & 3.57 & 5.08 & 2.38 & 3.75 \\
\hline \multicolumn{7}{|l|}{ F. silvestris tartessia (southern Spain) } \\
\hline S1 male (present study) & & 6.10 & 4.75 & 6.45 & 2.95 & 4.40 \\
\hline \multirow[t]{2}{*}{$S 2$ female (present study) } & & 5.20 & 4.10 & 6.15 & 2.90 & 4.35 \\
\hline & mean $(n=2)$ & 5.65 & 4.43 & 6.30 & 2.93 & 4.38 \\
\hline \multirow{2}{*}{$\begin{array}{l}\text { F. silvestris tartessia (southern Spain) } \\
\text { modern }\end{array}$} & range & $5.3-5.6$ & $4.2-4.4$ & $6.1-6.8$ & $3.0-3.1$ & $3.8-4.5$ \\
\hline & mean $(n=2-3)$ & 5.50 & 4.33 & 6.37 & 3.07 & 4.33 \\
\hline \multirow{2}{*}{$\begin{array}{l}\text { F. silvestris silvestris (European sample) } \\
\text { modern }\end{array}$} & range & $3.6-5.6$ & $3.1-4.3$ & $5.3-6.2$ & $2.5-3.1$ & $3.8-4.5$ \\
\hline & mean $(n=16-23)$ & 4.52 & 3.51 & 5.73 & 2.83 & 4.17 \\
\hline $\begin{array}{l}\text { F. silvestris (Palestinian sample) } \\
\text { postglacial }(\sim 7600 \mathrm{BP})^{d}\end{array}$ & mean $(n=10-21)$ & 4.68 & 3.65 & 5.44 & 3.00 & 4.40 \\
\hline $\begin{array}{l}\text { F. silvestris (Palestinian sample) } \\
\text { late Main Würm }(\sim 15,000 \mathrm{BP})^{c . d}\end{array}$ & mean $(n=5-10)$ & 5.98 & 4.23 & 6.41 & 3.12 & 4.54 \\
\hline $\begin{array}{l}\text { F. silvestris (Palestinian sample) } \\
\text { early Main Würm }(\sim 25,000 \mathrm{BP})^{d}\end{array}$ & mean $(n=6-13)$ & 5.70 & 4.40 & 6.64 & 3.33 & 4.72 \\
\hline
\end{tabular}

All data are in millimeters. Measurements were taken from teeth of the lower jaw. $\mathrm{Ci}$, canine; $\mathrm{P}_{3}$ and $\mathrm{P}_{4}$, the two premolars; $\mathrm{M}_{1}$, the mandibular molar tooth; Protoc. the protoconid cusp; Parac., the paraconid cusp.

${ }^{a}$ Eleven to 13 parameters were compared to generate the $t$ scores.

${ }^{h}$ For tests of significance, degrees of freedom was typically set at a conservative value ( $n$ of teeth - 1 ).

Retinal ganglion cell analysis. The analysis of the distribution and types of retinal ganglion cells was also carried out using DIC optics. We measured the depth of ganglion cell dendrites with reference to the inner border of the inner nuclear layer or the equator of ganglion cell bodies using a linear encoder (Heidenhain M25; $0.1 \mu \mathrm{m}$ resolution; accuracy, $0.3 \mu \mathrm{m}$ over $25 \mathrm{~mm}$ ). The tip of this encoder rested on the stage. Highmagnification plots of ganglion cells (e.g., Fig. 7) were made by overlaying the video image of the retina onto a graphics program with variable magnification (as shown in Fig. $11 F$ ). The coordinates of ganglion cells on these plots are accurate to within $10 \mu \mathrm{m}$. Low-power plots were made using a drawing attachment and a $4 \times$ planapochromatic objective.

The classification of retinal ganglion cell types (on-center vs. offcenter; alpha, beta, and gamma cell types) was carried out using a $100 \times$ 1.25 NA planachromatic objective and DIC optics. On-center and off-

\section{'Data source; Kurtén (1965b).}

${ }^{d}$ Data source; Kurtén (1965a).

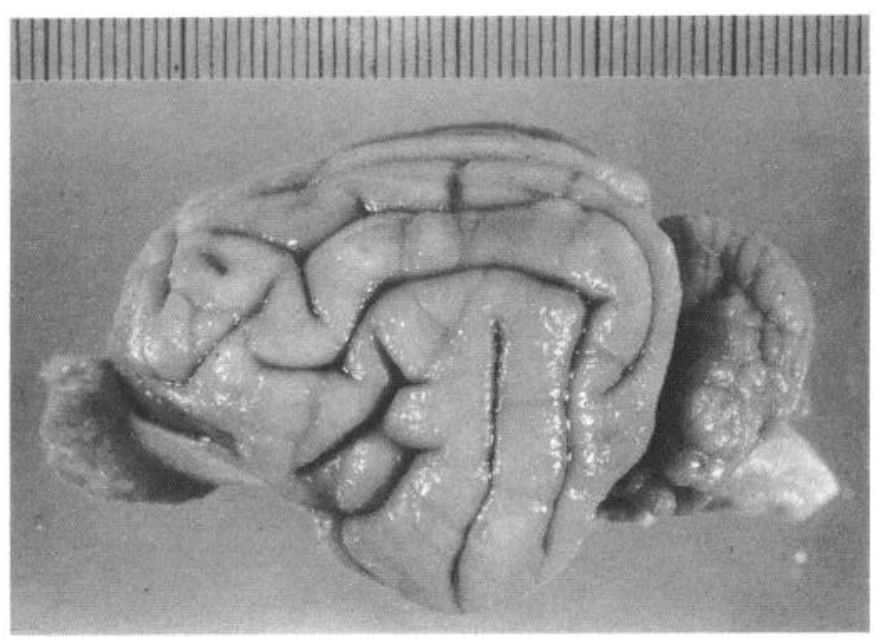

center cells have dendritic arbors in the inner and outer parts of the inner plexiform layer, respectively (Peichl and Wässle, 1981; Wässle et al., 1981a,b). With one or two exceptions, all alpha and beta cells in regions chosen for analysis could be confidently classified. For every cell that we categorized as on-center or off-center, we first measured the distance (depth) from the equator of the ganglion cell to the position of secondary and tertiary dendrites in the inner plexiform layer. The accuracy of these measurements was about $0.5 \mu \mathrm{m}$. Gamma cells could generally not be classified due to their poor dendritic labeling. Similarly, cells within $2 \mathrm{~mm}$ of the area centralis could not be identified reliably due to poor dendritic filling. In classifying cells in the wildcat, we have relied heavily on criteria developed in the domestic cat (Boycott and Wässle, 1974).

For the high-resolution sampling of ganglion cell densities in the area centralis and along the horizontal meridian, the distance between ad-

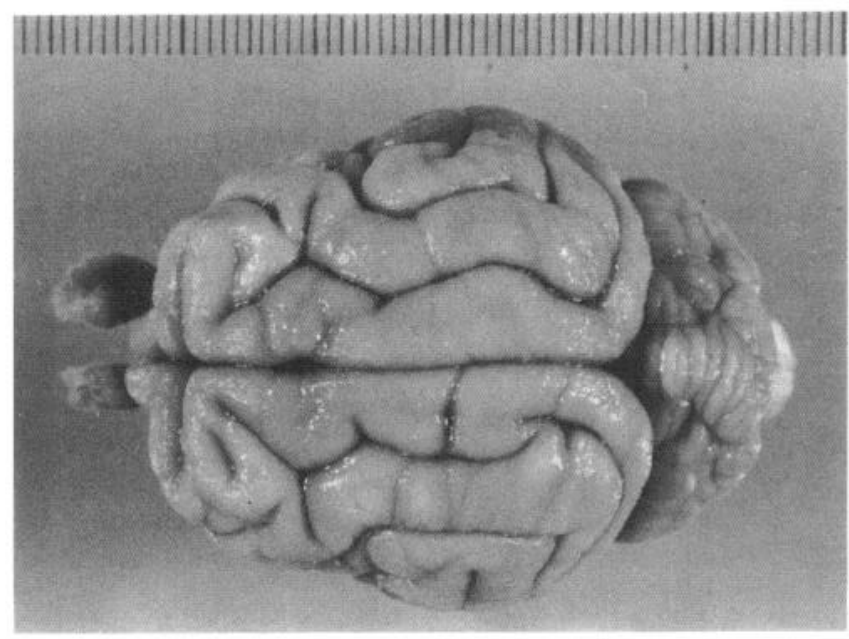

Figure 1. Left and dorsal lateral views of the brain of Felis silvestris tartessia, the Spanish wildcat (female S2). Sulcal patterns in this 31 gm brain conform to the type III pattern seen in about $18 \%$ of domestic cats (Fig. 7 in Otsuka and Hassler, 1962). 
Table 1. Continued

\begin{tabular}{|c|c|c|c|c|c|c|c|c|c|}
\hline \multicolumn{4}{|l|}{$\mathrm{P}_{4}$} & \multicolumn{4}{|l|}{$\underline{\mathbf{M}_{1}}$} & \multirow[b]{2}{*}{ Student's $t^{a}$} & \multirow[b]{2}{*}{$\begin{array}{l}\text { Statistical } \\
\text { results }^{h}\end{array}$} \\
\hline Length & Width & Height & $\begin{array}{l}\text { Protoc. } \\
\text { length }\end{array}$ & Length & Width & $\begin{array}{l}\text { Protoc. } \\
\text { height }\end{array}$ & $\begin{array}{l}\text { Parac. } \\
\text { height }\end{array}$ & & \\
\hline $7.0-7.5$ & $2.6-2.8$ & $4.3-4.7$ & $3.4-3.6$ & $7.2-8.1$ & $3.0-3.5$ & $4.6-5.2$ & $4.4-4.6$ & & \\
\hline 7.15 & 2.70 & 4.52 & 3.48 & 7.65 & 3.20 & 4.92 & 4.47 & $t=5.88$ & $p<.05$ at $\mathrm{df}=3$ \\
\hline 8.30 & 3.65 & 5.20 & 4.55 & 9.35 & 3.95 & 5.60 & 4.75 & & \\
\hline 7.90 & 3.35 & 5.10 & 3.80 & 8.45 & 3.75 & 5.30 & 4.65 & & \\
\hline 8.10 & 3.50 & 5.15 & 4.18 & 8.90 & 3.85 & 5.45 & 4.70 & reference & reference \\
\hline $7.3-7.9$ & $3.5-3.9$ & $4.4-5.2$ & $3.7-4.2$ & $7.4-9.0$ & $3.9-4.5$ & $5.8-6.1$ & $4.2-4.7$ & & \\
\hline 7.57 & 3.67 & 5.07 & 3.97 & 9.05 & 4.20 & 5.95 & 4.45 & $t=-0.04$ & no difference \\
\hline $6.2-8.2$ & $2.9-3.5$ & $4.4-5.2$ & $3.5-4.0$ & $7.4-9.0$ & $3.2-3.9$ & $4.7-5.7$ & $3.2-4.4$ & & \\
\hline 7.10 & 3.26 & 4.83 & 3.71 & 8.26 & 3.54 & 5.25 & 4.03 & $t=7.11$ & $p<.01$ at $\mathrm{df}=3$ \\
\hline 7.49 & 3.56 & 5.54 & 4.08 & 8.74 & 3.80 & - & 4.28 & $t=2.41$ & $p<.05$ at df $=11$ \\
\hline 7.96 & 3.71 & 5.57 & 4.41 & 9.48 & 4.11 & 4.98 & 3.9 & $t=0.64$ & no difference \\
\hline 8.08 & 3.89 & 5.49 & 4.28 & 9.62 & 4.21 & - & - & $t=-3.30$ & $p<.05$ at $\mathrm{df}=3$ \\
\hline
\end{tabular}

jacent sample sites varied from $35 \mu \mathrm{m}$ in the area centralis to $200 \mu \mathrm{m}$ in the far periphery. Sites were studied with a $100 \times 1.25$ NA planachromatic objective. Each site had an area of $1200 \mu \mathrm{m}^{2}$. Sampling and counting procedures were unbiased (Brændgaard and Gundersen, 1986), and no adjustments were made to avoid blood vessels or axon fascicles or small tears in the whole-mount. For the purpose of counting, we used the nucleolus as the criterion structure. Data were collected separately for labeled and unlabeled cells in the ganglion cell layer. We excluded glial cells, characterized by their small bodies and minuscule nucleoli (Wong and Hughes, 1987a) from analysis. To determine peak densities of ganglion cells in the area centralis, we used video-enhanced DIC optics to analyze sets of highly magnified fields $\left(450 \mu \mathrm{m}^{2}\right.$ at $\left.6500 \times\right)$. To calculate the peak density of ganglion cells we used the highest average of six adjoining fields.

Numbers of axons in the optic nerve. We prepared cross sections of the mid-orbital part of the optic nerve for analysis as described in previous work (Williams and Chalupa, 1983; Williams et al., 1986). Counts of axons were obtained in a systematically distributed sample of fields (typically 50-100), and our estimate of average axon packing density was multiplied by the cross-sectional area of the nerve to obtain an estimate of the total axon population. A change in sampling protocol was required because of the large area of the wildcat optic nerves. The ultrathin sections of the wildcats were too large to fit onto single grids. Consequently, several grids had to be photographed to sample the entire cross section of the nerve. Electron micrographs covered fields of 467 $\mu \mathrm{m}^{2}$. The sample area was determined with the aid of a mesh calibration grid photographed at the end of the sampling session. Axons in cats are unbranched, and therefore the number of optic axons provides a good estimate of the retinal ganglion cell population (Chalupa et al., 1984; Lia et al., 1986).

In the case of the fetal wildcat, 20-25 systematically distributed fields, each with an area of $93 \mu \mathrm{m}^{2}$, were photographed and counted in each optic nerve. Numbers of axons, growth cones, and necrotic fibers were counted in each field, using the same criteria developed in Williams et al. $(1986,1991)$.

$L G N$ cell analysis. We estimated the total population of neurons in the LGN in both frozen and celloidin-embedded material by means of direct three-dimensional counting using oil immersion objectives and DIC optics (Williams and Rakic, 1988b). The main advantage of threedimensional counting is that no correction factors-particularly, the often inaccurate Abercrombie correction - are required to estimate local cell density. Furthermore, this method is insensitive to variation in processing methods and section thickness. Neurons in the LGN were distinguished from glial cells and endothelial cells on the basis of size and nuclear staining as described in detail in Williams and Rakic (1988a). Neuronal nuclei, both of principal neurons and interneurons, were counted in translaminar probes extending through layers $\mathrm{A}, \mathrm{Al}, \mathrm{C}, \mathrm{Cl}$ $\mathrm{C} 2$, and $\mathrm{C} 3$ (and the medial interlaminar nucleus in the most medial probes). Between nine and 11 probes were made through each nucleus in regions representing upper, lower, central, and peripheral visual fields. Each probe was made up of a series of adjacent counting boxes. The depth of the counting box-the z-axis of the section-was optimized for the thickness of the individual section. We used the linear optical encoder to define the tops and bottoms of counting boxes. The average density of ncurons in the counting boxes was calculated and multiplied by the volume of the nucleus to obtain the total LGN neuron population.

The volume of the LGN was determined by direct integration. To do so, the areas of eight or more sections through each nucleus were measured and plotted against the rostral-caudal (or, in some cases, dorsalventral) position of the section. A curve was fit by eye through the points, and the area under this curve-an accurate estimate of total LGN volume-was determined. Although this method is not as simple as several alternatives described in Rosen and Harry (1990), it provides a useful graphic assessment of the shape of the nucleus, and it allowed us to detect and correct errors made during drawing and measuring the LGN cross sections.

The size distribution of neurons in the LGNs of wildcats and domestic cats was studied in celloidin-embedded tissue. The cross-sectional areas of ccll bodics wcre measured directly onscreen at $2000 \times$ using a videoenhanced DIC overlay system (Williams and Rakic, 1988a) through layers $\mathrm{A}, \mathrm{Al}$, and the $\mathrm{C}$ layers. A $100 \mu \mathrm{m}$ graticule divided into $2 \mu \mathrm{m}$ increments was used to calibrate all images.

\section{Results}

We have studied two adult wildcats and one fetal wildcat. These animals were extremely difficult to obtain and there was no immediate prospect for increasing numbers of cases. Therefore, our approach has been to analyze the material in detail, as if we had uncovered a small number of rare and important fossils. In some cases, our analysis of the wildcats has extended beyond data initially available for the domestic cat. This is true for the analyses of photoreceptor distribution and dendritic differences among on-center and off-center beta cells. Despite the small sample size, the central results of this study-the marked differences in populations of retinal ganglion cells and of geniculate 

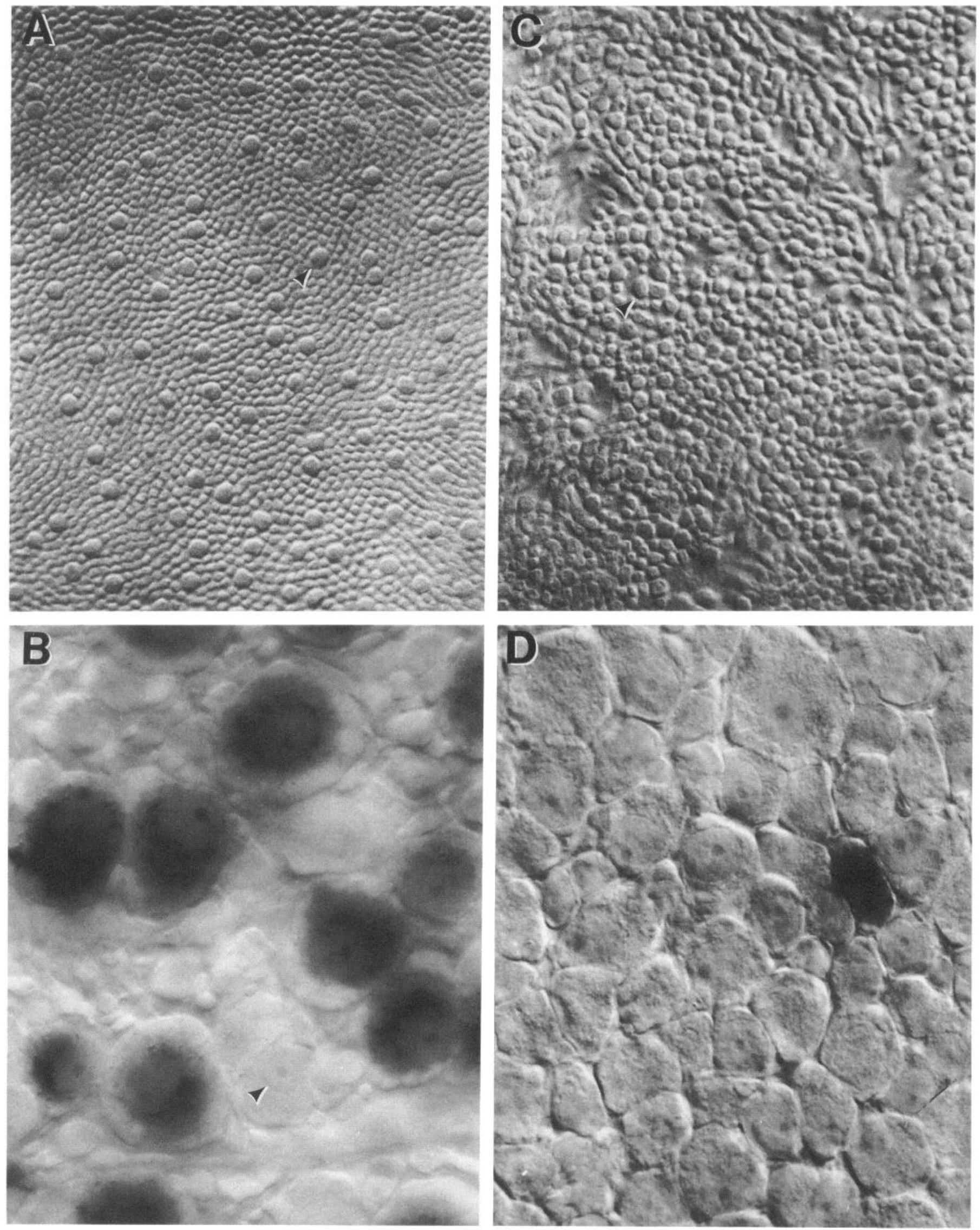

Figure 2. The photoreceptor mosaic and ganglion cell layers of the male wildcat $S 1$. All images cover an area $78 \times 100 \mu \mathrm{m} . A$ and $B$ are pairs of DIC images of precisely the same area of a retinal whole-mount, $0.5 \mathrm{~mm}$ above the area centralis close to the decussation line in temporal 
neurons-do achieve statistical significance. With respect to other facets of this study, particularly those based on single animals, we have tried to be circumspect in our conclusions and to point out interpretative caveats. In several instances, we provide more complete documentation for the wildcats than for domestic cats. References to spccific figures for domestic cats are made both in the text and in figure captions.

\section{Comparison of body weight and brain size of the two species}

The average body weight of $F$. silvestris tartessia males is about $6.5 \mathrm{~kg}$, and of females about $4 \mathrm{~kg}$ (Rodriguez de la Fuente, 1979). Our two wildcats were lean and weighed less than average: the male $(S I)$ weighed $3.7 \mathrm{~kg}$ and the female $(S 2)$ weighed $3.3 \mathrm{~kg}$. Despite these modest body weights, the brains of the male and female wildcats weighed $37 \mathrm{gm}$ and $31 \mathrm{gm}$, respectively. These values are far above the domestic cat average: $27.6 \mathrm{gm}$ with an $\mathrm{SD}$ of $\pm 1.5 \mathrm{gm}$ for male domestic cats, and $26.5 \pm 1.35 \mathrm{gm}$ for females (Latimer, 1938). Even the brain weight of the small female wildcat reproduced in Figure 1 is 3.3 SDs above that of female domestic cats. Our huge $9 \mathrm{~kg}$ male domestic cat had a brain weight of only $28.25 \mathrm{gm}$. This is $9 \mathrm{gm}$ less than the brain weight of the less massive but equally tall male wildcat. In absolute terms, the difference in brain weight between the two adult wildcats and domestic cats is in the neighborhood of 20$30 \%$. This difference conforms closely to that which we anticipated based on the allometric relationship between brain and body weights derived from a wide range of felids-brain mass $\approx 0.23$ (average body mass) (.61 $^{0.6}$ (Davis, 1962; Radinsky, 1975; Pagel and Harvey, 1989).

The pattern of gyri and sulci in wildcats conforms to the typical field pattern (Fig. 1; cf. Radinsky, 1975). The lateral, posterolateral, and suprasylvian gyri are arranged in a common pattern that Otsuka and Hassler (1962) refer to as type III. The lateral and suprasylvian gyri are wider in the wildcats than is typical in domestic cats. For example, the lateral gyrus was between 7.0 and $8.5 \mathrm{~mm}$ wide in the wildcats compared to typical values between 5.0 and $6.5 \mathrm{~mm}$ in domestic cats (in vivo values, Reinoso-Suárez, 1961). Although the breadth of the cranium is greater in wildcat, the stereotaxic coordinates of bregma and inion do not differ appreciably between species. The thickness of bones of the cranial vault is much reduced in wildcats (e.g., the thickness of the temporal bone is merely $1.25 \mathrm{~mm}$ in wildcat vs. $2.6 \mathrm{~mm}$ in domestic cats). In this case, the thick skulls of domestic cats do house smaller brains.

\section{Analysis of retinal structure}

Constancy of retinal dimensions

There is complete overlap in the area of wildcat and domestic cat retinas. The range among the four wildcat retinas is from
528 to $570 \mathrm{~mm}^{2}$, whereas the range among domestic cats is from 460 to $640 \mathrm{~mm}^{2}$ (Hughes, 1975; Chalupa et al., 1984; present results). Our huge domestic cat had retinal areas of 570 and 600 $\mathrm{mm}^{2}$. Linear retinal measurements are also equivalent: the distance from the center of the area centralis to the center of the optic disk in the wildcat retinas is between $3.37 \mathrm{~mm}$ ( $S 2 \mathrm{right})$ and 3.55 ( $S 1$ right), precisely in the same range as that reported in Nikara et al. (1968), Wässle et al. (1975), and Hughes (1975). It is also likely that posterior nodal distances and retinal magnification (about $213 \mu \mathrm{m}$ per degree near the area centralis) in the two species are the same.

\section{Differences in rod and cone distributions}

A quantitative analysis of the photoreceptor mosaic was possible in both retinas from the male wildcat $S 1$. Data from this animal demonstrate that densities of cone photoreceptors can reach higher densities in wildcats than has ever been reported in domestic cats. The difference appears to be most marked in the central retina, particularly at the center of the area centralis, where cone densities of up to $100,000 / \mathrm{mm}^{2}$ were encountered in this wildcat (Fig. 2). In comparison, the highest cone density we have yet encountered in domestic cats is $35,000-40,000$ / $\mathrm{mm}^{2}$, a range that is itself about $25 \%$ higher than peak cone densities reported in previous studies of this species (Steinberg et al., 1973, their Figs. 1, 2, 6; Wässle and Riemann, 1978, their Fig. 2). Cone densities are also high in the periphery of this wildcat's retinas (Figs. 3,4). However, the difference is not as great as in the area centralis. For example, along most of the horizontal meridian, cone densities are only $20-30 \%$ higher than in the domestic cat at comparable eccentricities. Although not studied in the same detail, there also appears to be a comparative surplus of cones in dorsal and ventral retina of the wildcat in comparison to the domestic cat. To obtain a rough estimate of the difference in the total cone population, we integrated the area under the curves in Figures 3 and 4. The ratio of these areas is $1: 1.3$ (domestic: wildcat). Therefore, along this axis, domestic cats typically have $25 \%$ fewer cones than does wildcat $S 1$.

Conversely, rod densities were much lower in the area centralis of wildcat $S 1$ than has ever been measured in domestic cats (Steinberg et al., 1973; present results). Rod densities drop to well under $50,000 / \mathrm{mm}^{2}$ in the center of the area centralis of $S I$ (Fig. 2), but in domestic cats we have been unable to locate any fields in the area centralis of any animal in which rod densities fall to less than $200,000 / \mathrm{mm}^{2}$. Along most of the horizontal streak of the wildcat, rod densities average between $300,000 / \mathrm{mm}^{2}$ and $400,000 / \mathrm{mm}^{2}$. This is on the low side of the range we have observed in the horizontal streak of domestic cats. In both species, rod densities range up to 550,000 in the dorsal periphery. To estimate the difference in the rod popu-

\footnotetext{
hemiretina (ipsilateral to the HRP injections). The two micrographs were taken at focal planes separated vertically by $74 \mu \mathrm{m} . A$, Micrograph at the level of the photoreceptor inner segments. Large cone inner segments stand out clearly among the small rod inner segments. A single cone is marked by a small arrowhead. This image can be compared to those reproduced in Figure 2 of Steinberg et al. (1973) and Figure 2 of Wässle and Riemann (1978). B. Micrograph taken at the level of the ganglion cells. Most of thesc cells arc labcled with the dark HRP reaction product, but at least one unlabeled cell with a large nucleolus is also a ganglion cell (arrowhead), presumably one that has a crossed projection. $C$ and $D$, Comparable through-focus pairs of micrographs taken in the area centralis. Note that the cones in area centralis, one marked by an arrowhead, are somewhat smaller than in $A$ and are much more densely packed (densities range from 50,000 to 100,000). Smaller rods are also scattered throughout the area centralis. We have not been able to find regions of such high cone density in domestic cats, nor have other investigators (see Steinberg et al., 1973, their Fig. 2). In $D$, only a single labeled ganglion cell is present in this field just nasal to the decussation line in the retina ipsilateral to the central HRP injections. Only 49 other ganglion cell bodies are visible in this focal plane. However, ganglion cells are stacked two or three cells deep here, and this small field actually contains 112 ganglion cells. This is equivalent to a density of $14,400 \mathrm{cells} / \mathrm{mm}^{2}$.
} 


\section{Wildcat Photoreceptor Distribution Profile}

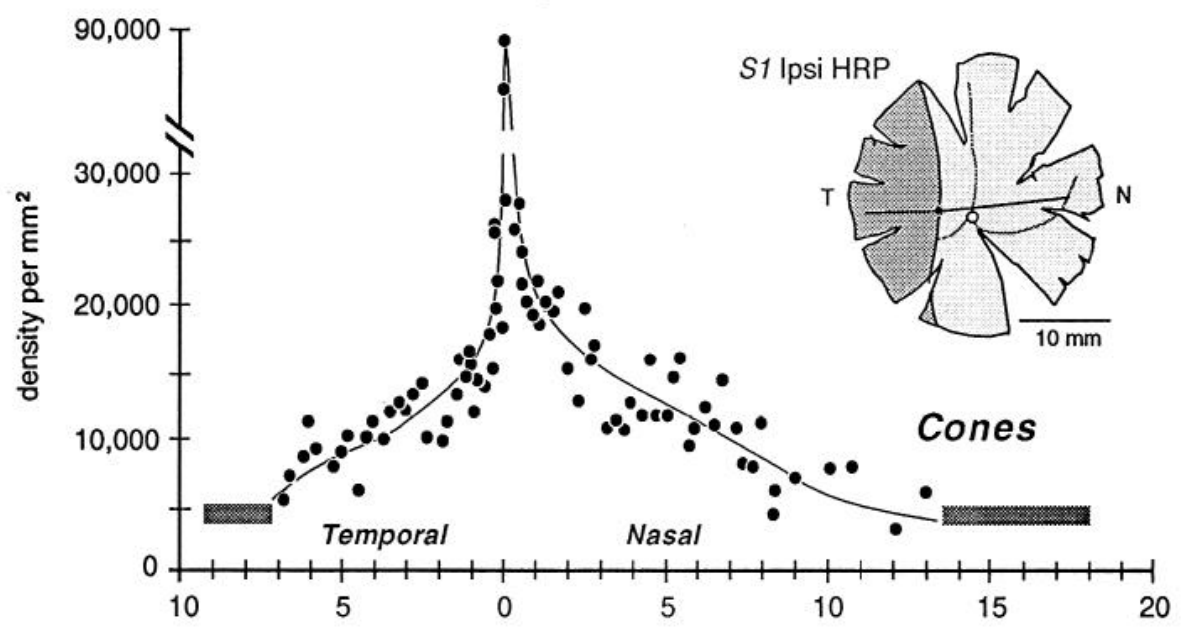

Figure 3. Gradients in wildcat cone and rod densities through the area centralis and along the horizontal axis (male wildcat $S 1$ ). The vertical axes in this figure and Figure 4 (domestic cat) are identical except that the $y$-axis is interrupted above $30,000 \mathrm{~mm}^{2}$. The gray bars at the far right and left of these plots represent eccentricities at which we could not make accurate measurements because of excessive retinal pigment. A sketch of the ipsilateral HRPlabeled retina in the upper right shows the horizontal line along which data were collected. $T$, temporal; $N$, nasal.



lation, we again integrated the area under the curves (Figs. 3, 4). The ratio is 1.2:1 (domestic: wildcat).

\section{Marked differences in ganglion cell numbers and distribution}

Total ganglion cell densities are substantially higher in all retinas of both wildcats than in domestic cats, both in the area centralis and across the retinal periphery (Fig. 5). For example, in the area centralis, ganglion cell densities are $50 \%$ to nearly $100 \%$ higher in the wildcats than in domestic cats. In particular, the peak density of HRP-labeled ganglion cells in the right retina of $S 1$ (contralateral to the injected hemisphere) is 15,100 cells/ $\mathrm{mm}^{2}$ at a location $40 \mu \mathrm{m}$ nasal to our estimate of the position of the center of the decussation line (Fig. $6 A, B$ ). At the decussation line itself, the density of labeled and unlabeled cells in $S 1$ is 10,100 and 5,900 cells $/ \mathrm{mm}^{2}$, respectively, giving a peak density of about $16,000 / \mathrm{mm}^{2}$. In wildcat $S 2$, a case in which both retinas were stained with toluidine blue, the peak density of cells with large nucleoli in the area centralis is 18,400 in the left retina (Fig. $6 D$ ) and 20,900 in the right retina. In comparison, the highest packing density of HRP-labeled retinal ganglion cells we have found in the center of the area centralis of a domestic cat is $10,500 / \mathrm{mm}^{2}$ (Fig. 5, bottom). This value matches peak ganglion cell densities reported in numerous previous studies of domestic cat retina (Hughes, 1975; Stone, 1978;
Stone et al., 1982; Chalupa et al., 1984; Wong and Hughes, 1987b). It is probable that the reduction in cone and ganglion cell densities in the area centralis of the domestic lineage has been matched by a reduction in sampling resolution of both cell arrays, as well as in photopic acuity. Ganglion cell densities in the periphery are also greater in both wildcats than in domestic cats. However, the quantitative difference is less marked, averaging $15-25 \%$ (Fig. 5). For example, in the field of cells depicted in Figure 7, the density of HRP-labeled ganglion cells is $300 / \mathrm{mm}^{2}$ at a mean eccentricity of $9.4 \mathrm{~mm}$. At this eccentricity in the domestic cat, ganglion cell densities are typically $\sim 200$ / $\mathrm{mm}^{2}$ (Figs. 5, bottom; 8; see also Stone, 1978; Chalupa et al., 1984).

Decussation pattern does not differ. The pattern of decussation of ganglion cell axons was examined in wildcat $S I$ by retrograde labeling from one hemisphere (Fig. 6A,B). The characteristics of the decussation pattern and the relative sizes of the temporal and nasal retinal components appear indistinguishable at a qualitative level from those noted in domestic cats by previous investigators (Cooper and Pettigrew, 1979; Jacobs et al., 1984, their Fig. 1).

The horizontal streak. We were struck by the prominence of the horizontal streak in the wildcat retinas. However, our quantitative analysis revealed that the increment in cell density in 


\section{Domestic Cat Photoreceptor Distribution Profile}
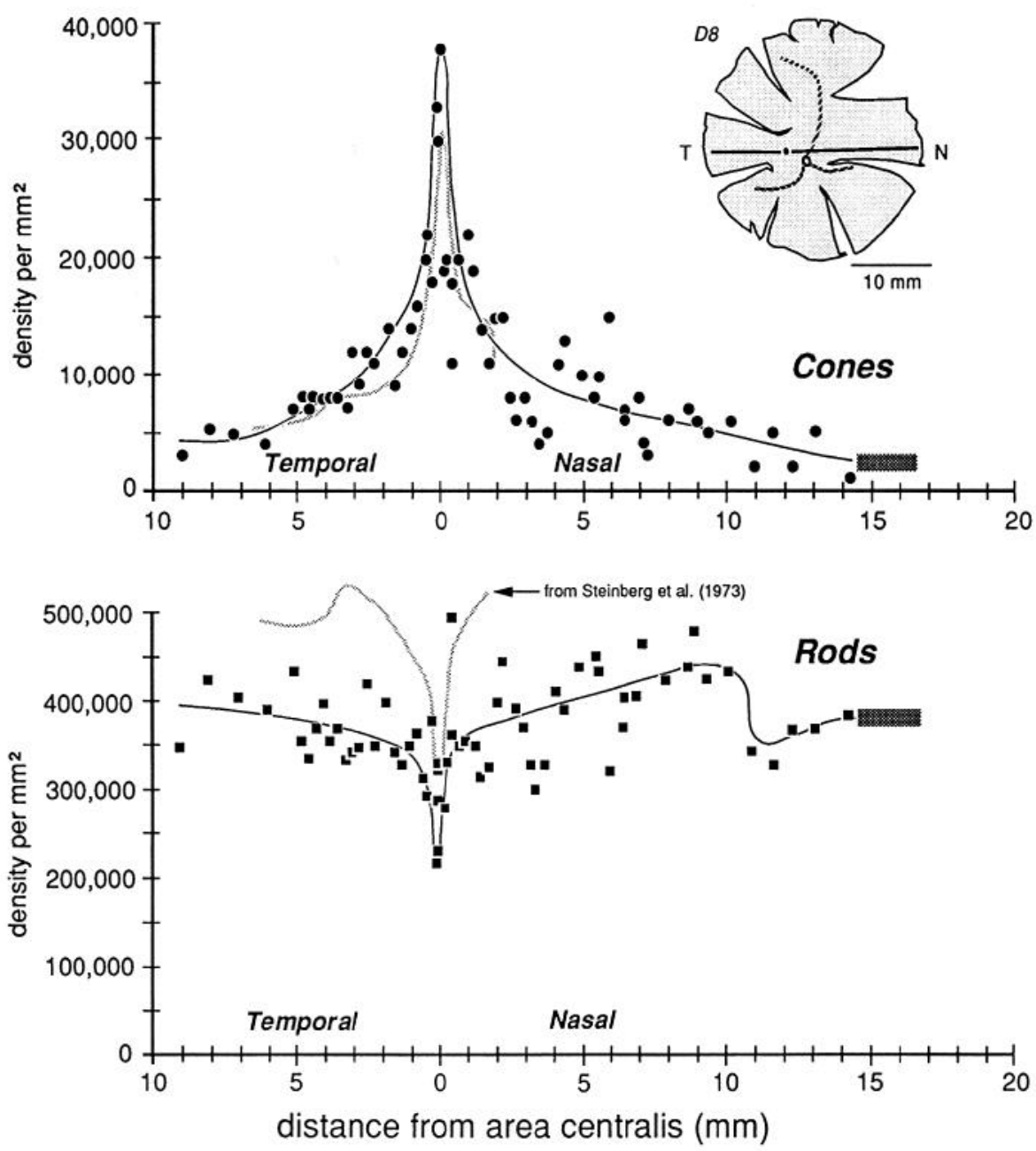

Figure 4. Gradients in domestic cat cone and rod densities through the area centralis and along the horizontal axis (domestic cat D8). Faint gray curves in both $A$ and $B$ are taken from data in Steinberg et al. (1973). $T$, temporal; $N$, nasal. the wildcat streak is of the same magnitude as that seen elsewhere in peripheral retina (Fig. 5). For example, the density of labeled retinal ganglion cells in the mid-nasal periphery of the visual streak (6-12 mm eccentricity) averages 1000 cells $/ \mathrm{mm}^{2}$ in wildcat $S 1$ and about $600-700$ cells $/ \mathrm{mm}^{2}$ in domestic cats (Rowe and Stone, 1976; Chalupa et al., 1984).

Given the lower densities of ganglion cells in the domestic cat, most prominently around area centralis, one might expect a compensatory increase in the spread of dendritic fields in order to conserve field overlap (Wässle et al., 1981b). To answer this question unequivocally would require more complete dendritic filling than we have been able to achieve in either beta or gamma cell classes. However, the marked species differences in ganglion cell density at the area centralis and the sharp peak in cone density in wildcat $S 1$ suggest that photopic visual acuity is higher in wildcat than domestic cat.

Conservation of alpha cell number and distribution. While the total ganglion cell density is higher in wildcats than has ever been reported in the domestic cat, this is not true of one particular ganglion cell class: densities of alpha cells are almost precisely the same in both species (Fig. 9). For example, alpha cell density in the area centralis is between 120 and 150 cells/ $\mathrm{mm}^{2}$ in both wildcats, whereas in domestic cats, alpha cell density is between 130 and 200 cells $/ \mathrm{mm}^{2}$ (our data from three domestic cats; cf. Wässle et al., 1975; Stone, 1978; Kirby and Chalupa, 1986). We counted 410, 425, and 428 HRP-labeled alpha cells in a 3 -mm-high $\times 2$-mm-wide region located just nasal to the area centralis in three domestic cats. In comparison, we counted 411 HRP-labeled alpha cells in the same area in wildcat $S 1$. Similarly, we identified a total of 1412 Nissl-stained alpha cells in the $36 \mathrm{~mm}^{2}$ region centered on the area centralis in wildcat $S 2$ (Fig. 9), while Wässle et al. (1975, their Figs. 6A, $8 A$ ) identified 1484 alpha cells in an equal area in a domestic cat-a difference of merely $5 \%$. Densities of alpha cells are also remarkably close in the mid and far periphery of both species. For instance, the density of HRP-labeled alpha cells 9-10 mm above the area centralis in dorsal retina just nasal to the decussation line is $14 / \mathrm{mm}^{2}$ in wildcat $S 1$ and $11 / \mathrm{mm}^{2}$ in wildcat $S 2$. In domestic cats, values in this region range between 10 and $13 / \mathrm{mm}^{2}$ (Wässle et al., 1975, their Fig. 6A; Stone, 1978, his Fig. $5)$. Thus, it seems highly probable that the total alpha cell population in wildcats is in the same range as that for the domestic cat -5000 to 7000 (Wong and Hughes, 1987a).

No decline in alpha cell density in the wildcats' area centralis. In wildcat $S 1$, the pattern of HRP-labeled cells allowed us to define the location of the center of the area centralis with a precision of $\pm 25 \mu \mathrm{m}$, independent of the alpha cell distribution itself (Fig. $6 A, B$ ). This made it possible to assess whether there 


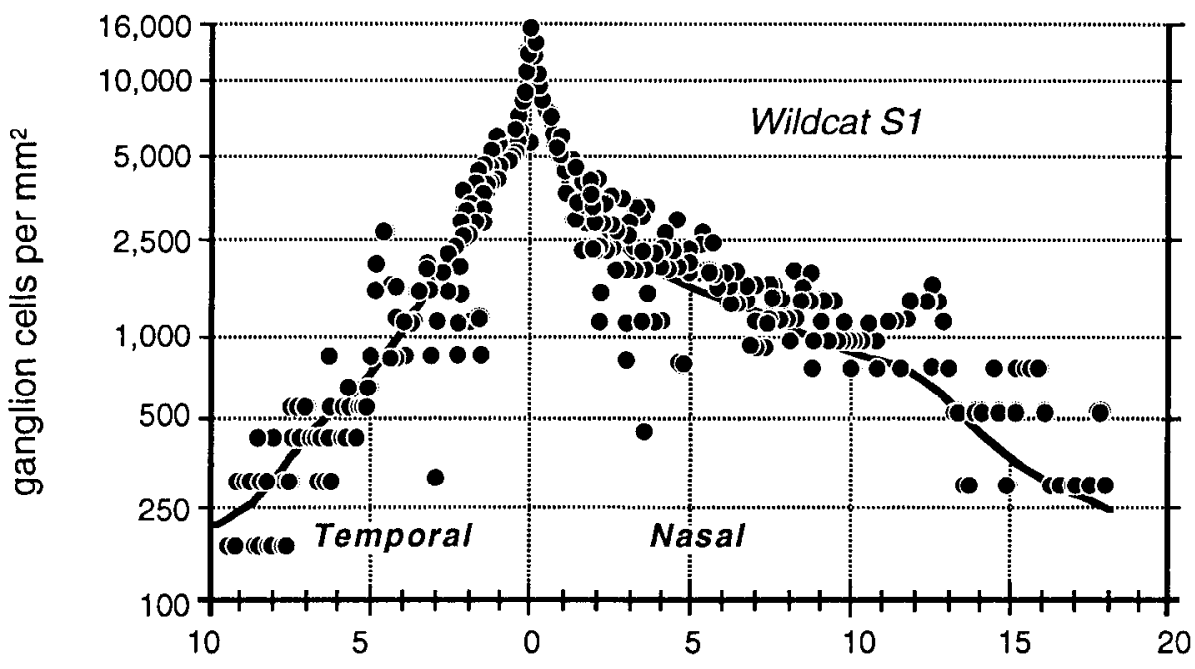

Figure 5. Central-to-peripheral gradient of ganglion cell density along the horizontal axis in wildcat $S I$ (top) and domestic cat DC15 (bottom). Qualitatively, the gradients are the same in both species, but densities are higher, most prominently around the area centralis of the wildcats. To obtain the plot in the top graph, numbers of HRP-labeled retinal ganglion cells were counted and summed in both retinas ipsilateral and contralateral to HRP injections (see Fig. 6). We sampled data in a completely unbiased manner and include fields traversed by large blood vessels. This accounts for some of the variability among data points.

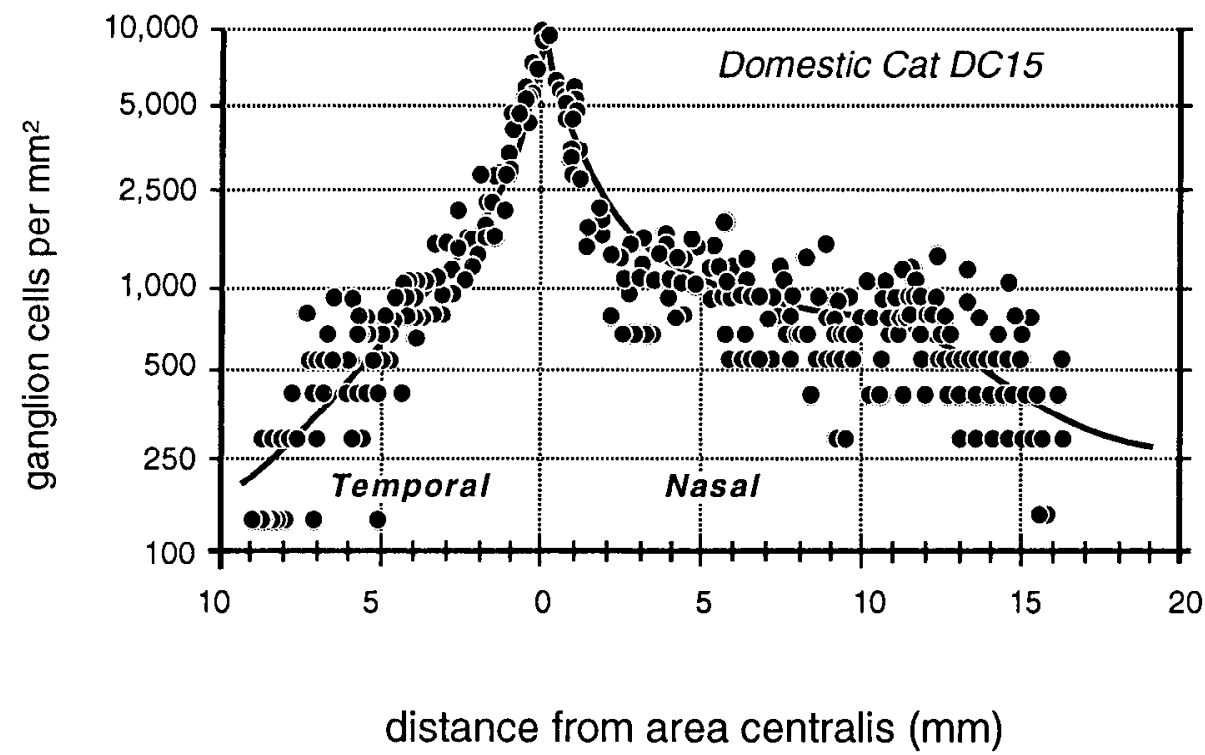

is a local decline in alpha cell density in the wildcat area centralis-an unresolved issue that has arisen in the domestic cat retina (Wässle et al., 1975; Stone, 1978; Mountcastle, 1980, p 539 ). In the wildcat, the density of alpha cells within a radius of $100 \mu \mathrm{m}$ of the center is $127 / \mathrm{mm}^{2}$, and in two slightly more peripheral annuli, densities are 121 and 132 alpha cells $/ \mathrm{mm}^{2}$. Nor was a central decline in alpha cell density noted in $S 2$ (Fig. 9). Similar analyses of HRP-labeled retinas from three domestic cats also did not demonstrate any appreciable decline in alpha cell density at the precise center of the area centralis.

Relative abundance of alpha, beta, and gamma ganglion cells are similar. The numbers of the alpha, beta, and gamma cell types were studied in the dorsal periphery of wildcat $S 1$. Here the proportions of HRP-labeled ganglion cell types are similar to those in domestic cats (Figs. 7, 8). Reta cells make up 50.2\% of the local ganglion cell population (155 of 309 cells), gamma cells make up $45.3 \%$, and alpha cells make up the remainder ( 14 of 309 cells in an area of $1.08 \mathrm{~mm}^{2}$ ). In the domestic cat, beta cells make up $48.9 \%$, gamma cells make up $45.3 \%$, and alpha cells make up the remainder ( 13 of 225 cells in an area of $1.08 \mathrm{~mm}^{2}$ ). Thus, ratios of cell types in a region of retina in which the assignment of cell types is unambiguous are similar in the two species. However, given the finding that the alpha cell population is the same in both species, but that the total population of ganglion cells is higher in wildcats, it is clear that the overall proportion of alpha cells must be slightly lower in wildcats than is typical in domestic cats (cf. Stone, 1978; Wong and Hughes, 1987a). Furthermore, at the area centralis of the wildcat, a region in which the total ganglion cell density is particularly high, alpha cells make up a smaller percentage $(<1 \%)$ of the cell population than in domestic cats $(2-3 \%)$.

As has also been noted in the domestic cat (Wässle et al., 1981 b; see also Fig. 8), there are slightly more off-center beta cells than on-center beta cells $(26.9 \%$ off-center, $22.7 \%$ on-center, $0.6 \%$ unknown) in the wildcat dorsal periphery (Fig. 7). Corresponding percentages for the domestic cat are $26.2 \%$ offcenter and $22.7 \%$ on-center cells (Fig. 8 ).

Ganglion cell size is the same. The higher average cell density in the wildcat retina could be associated with a reduction in mean cell body size. Such changes have been found following experimental manipulations in domestic cats (Kirby and Chalupa, 1986). We analyzed the sizes of all the cells in Figures 7 and 

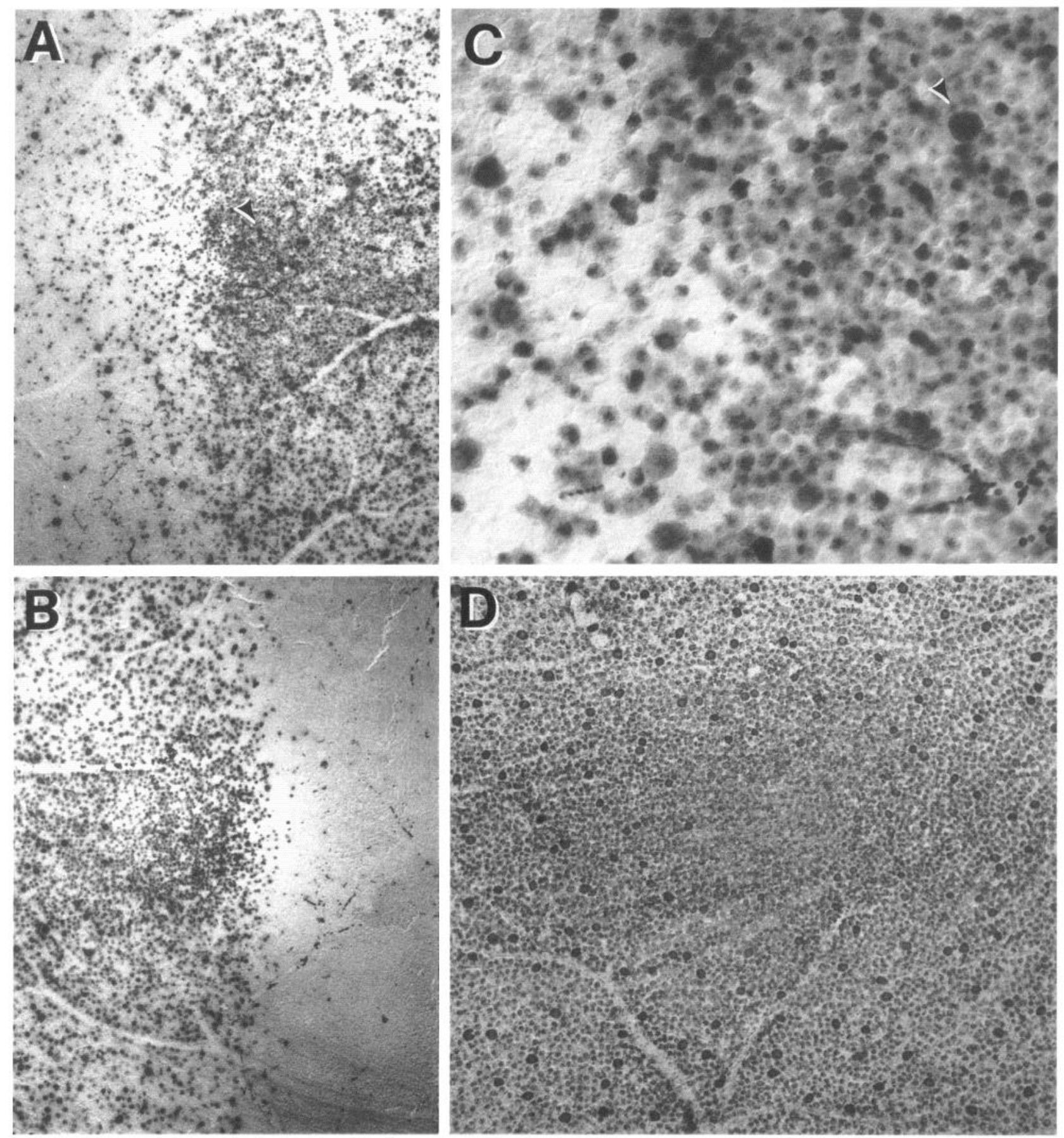

Figure 6. The area centralis of the wildcat retina and the precision of the line of decussation. $A$, The central region of the retina contralateral to hemispheric HRP injections in the male wildcat $S 1$. B. The ipsilateral left retina from the same animal. The regions shown in $A$ and $B$ are 1.08 $\mathrm{mm} \times 1.43 \mathrm{~mm}$. For alignment purposes, the left retina in $B$ has been oriented so that dorsal is down. In the wildcat, as in the domestic cat, there are numerous cells in temporal hemiretina that have crossed projections (left side of $A$ ), but there are very few cells in the nasal hemiretina that have uncrossed projections (right side of $B$ ). Comparable figures of the line of decussation in domestic cat are provided in Jacobs et al. (1984, their Fig. 1). $C$, Higher-magnification micrograph of the center of the area centralis. Note the relatively abrupt change in patterns of decussation as revealed by the degree of overlap of labeled and unlabeled retinal ganglion cells. Arrowheads in $A$ and $C$ point out a common landmark-a large alpha cell. Magnification in $C$ is $342 \times . D$, The entire area centralis in a Nissl-stained preparation from wildcat $S 2$. The large darkly stained cells are alpha cell bodies. Alpha cells in the center of the area centralis do not stain as darkly, in part because the ganglion cell layer is comparatively thick. The region of the wildcat area centralis in which ganglion cell densities are above $10,000 / \mathrm{mm}^{2}$ is small, corresponding approximately to a circle with a radius of $150 \mu \mathrm{m}$ (see Fig. 9). In this zone, the ganglion cell layer is typically two cells thick. Magnification in $D$ is $72 \times$, and the field is $1.36 \mathrm{~mm} \times 1.25 \mathrm{~mm}$ in horizontal and vertical dimensions. 
Figure 7. Retinal ganglion cell mosaic ers an area of about $1 \mathrm{~mm}^{2}$ in the dorsal part of the retina. Coordinates are indicated on the axes. Large off-center alpha cells are represented by black irregular shapes. On-center alpha cells are similar, but white. On- and off-center beta cells are represented by the large circles-black for off-center, white for on-center, and gray for two beta cells of unknown subtype. The small circles represent the heterogeneous gamma cell class. Only a few of these cells could be categorized as on-center or off-center. in the wildcat $S 1$. This field of cells cov-

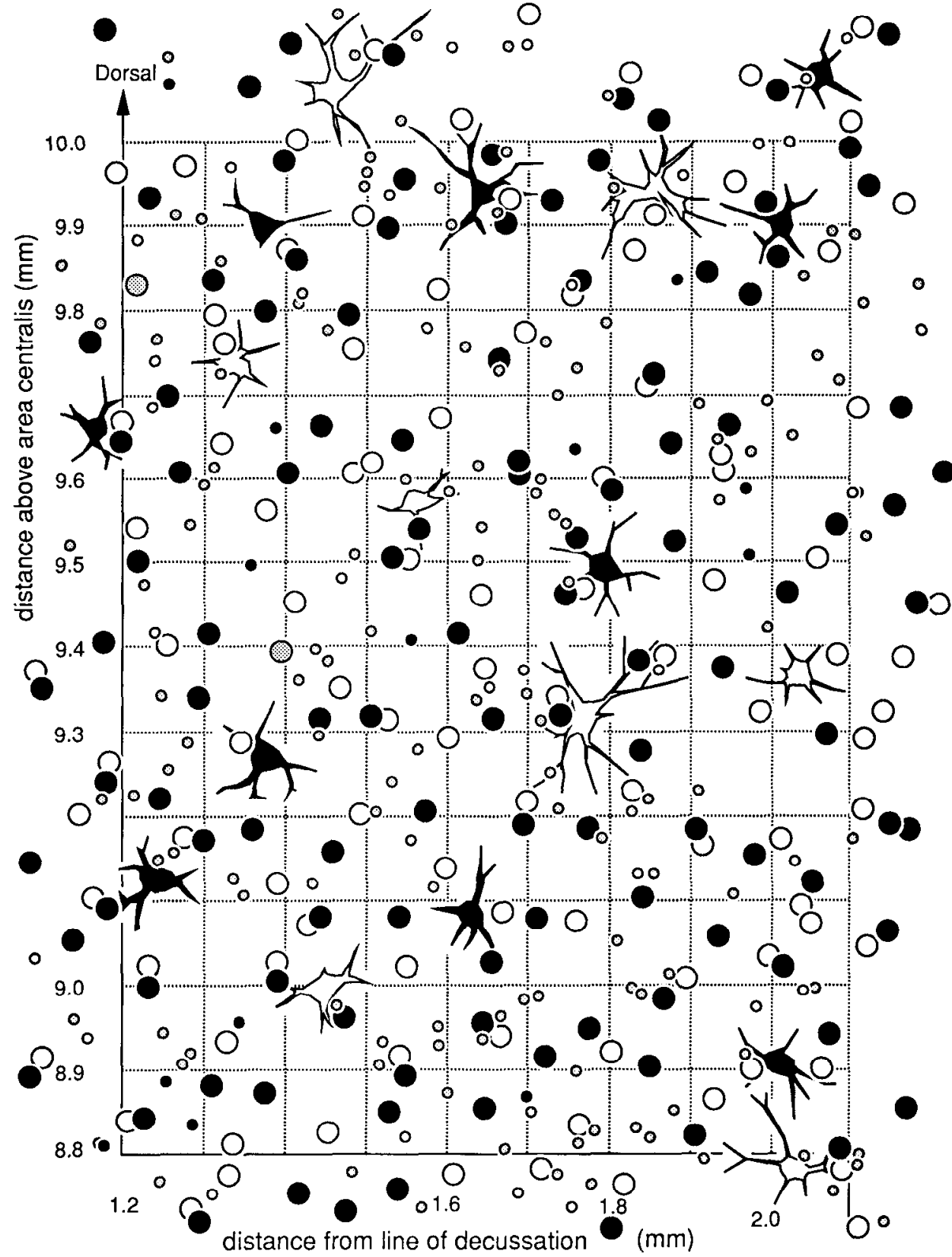

8. In wildcat $S 1$, the average cross-sectional area of 309 ganglion cells at a location $9 \mathrm{~mm}$ above the area centralis is $357 \mu \mathrm{m}^{2}$ (equivalent to an average diameter of $21.3 \mu \mathrm{m}$ ). In the domestic cat, the average size of the 230 ganglion cells in a comparable region, plotted in Figure 8, is almost precisely the same-359 $\mu \mathrm{m}^{2}$. This equality in ganglion cell size is remarkable given the sizable difference in the local density of ganglion cells -286 cells/ $\mathrm{mm}^{2}$ in the wildcat and $208 / \mathrm{mm}^{2}$ in the domestic cat.

More subtle differences in cell size between species are, in general, not masked by averaging across cell classes (Fig. 10). For example, the average beta cell diameter in $S I$ and the domestic cat $D C 13$ are both $23 \mu \mathrm{m}$. Similarly, the average diameters of gamma cells in $S 1$ and DC12 are both about $15 \mu \mathrm{m}$. However, cell size is quite variable among domestic cats, even at equivalent retinal coordinates. For instance, in domestic cat DCI2, the mean size of HRP-labeled retinal ganglion cells 9$10 \mathrm{~mm}$ above the area centralis was $472 \mu \mathrm{m}^{2}$ versus $359 \mu \mathrm{m}^{2}$ in another domestic cat, $D C 13$. It is also the case that HRPlabeled alpha cells in the wildcat $S I$ are smaller than in the domestic cats (Figs. 7, 8, 10). Given the small sample size, it seems prudent simply to conclude that data on cell size in wildcat $S I$ fall within the range seen in domestic cats.

Unsuspected dendritic differences between on-and off-center beta cells are conserved. The dendritic morphologies of on- and off-center beta cells in the wildcat differ consistently, both in the depth of their arborization (the standard criterion) and also in the shape of their proximal dendritic arbors (Figs. 11, 12). On-center cells almost invariably have three to five thin tapering and radiating primary dendrites (Figs. $11 B, E ; 12)$ that spread out directly from the cell body and arborize neatly in the inner half of the inner plexiform layer at a distance of 6-7 $\mu \mathrm{m}$ from the equator of the cell body. In contrast, off-center cells almost invariably have one or two thick primary dendrites that ascend sharply and then arborize in the outer third of the inner plexi- 


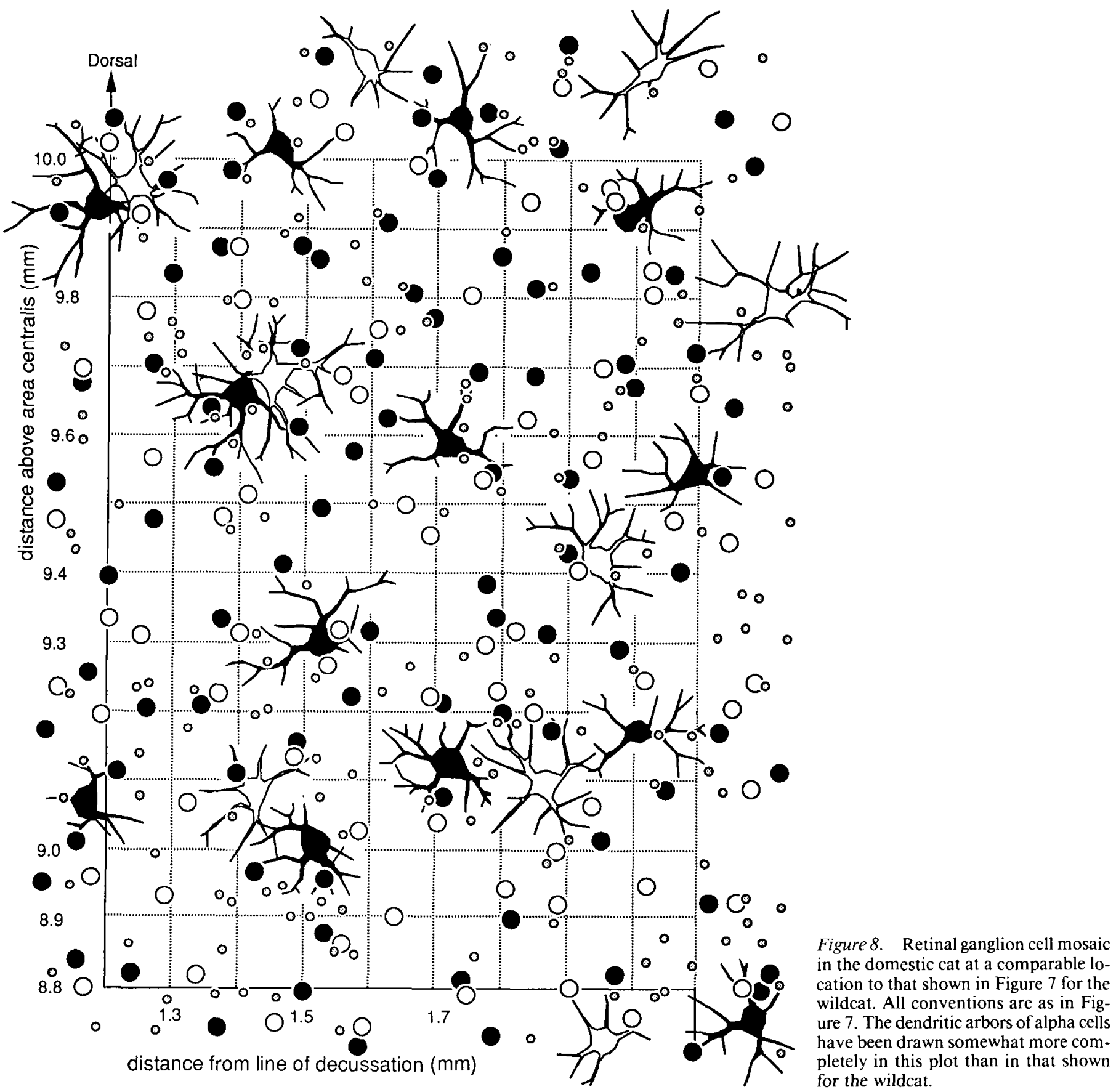

form layer (Figs. 11 $A, D, F ; 12$ ). Off-center arbors also have a more complex appearance than those of on-center beta cells, and the branch points of off-center arbors are often flared outward (Fig. 11). Off-center beta cell dendrites are almost invariably more curved (spraylike) than those of on-center cells and are broader and more heavily labeled with HRP. Off-center arbors are also most commonly disposed asymmetrically with respect to the cell body, whereas on-center cell dendrites radiate symmetrically. In wildcat $S l$, on- and off-center cells can be reliably identified using these characteristics without examining the depth of the dendritic arbor. These types of dendritic differences between on- and off-center beta cells have not been reported previously in the domestic cat, and because these cells have been studied in great detail, we initially assumed that this distinction must be unique to the wildcat. However, careful reexamination of retinas from several domestic cats revealed precisely the same dendritic differences first noted in wildcat S1.

\section{Analysis of the optic nerve}

Marked species differences in number of optic axons in adults The cross-sectional areas of the wildcats' optic nerves were substantially greater than those of domestic cats: $2.95 \mathrm{~mm}^{2}$ in $S I$ and $3.24 \mathrm{~mm}^{2}$ in $S 2$. This compares to a mean of about 2.0 $\mathrm{mm}^{2}$ in domestic cals (Williams et al., 1986). The packing density of fibers, however, is in the same range $-8.8 / 100 \mu \mathrm{m}^{2}$ in $S 1,7.22 / 100 \mu \mathrm{m}^{2}$ in $\mathrm{S} 2$ (Fig. 13A) and $\approx 8.0 / 100 \mu \mathrm{m}^{2}$ in domestic cats (Williams et al., 1983). Given these findings, it is not surprising that the total population of axons is much higher 


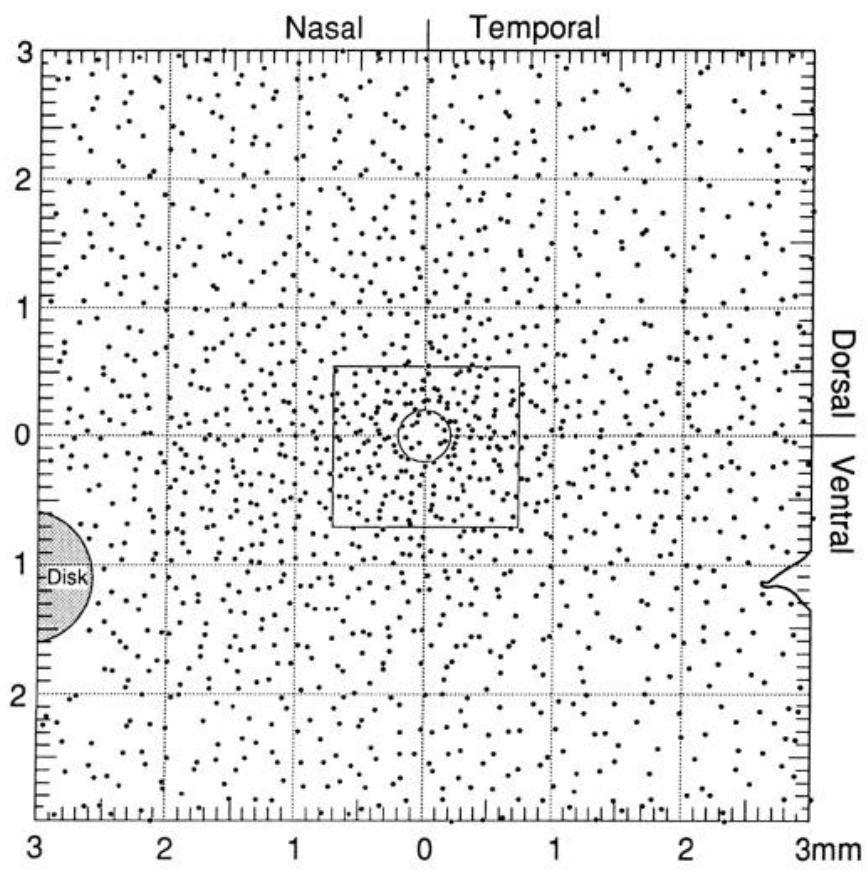

Figure 9. Alpha cell distribution in and around the area centralis of wildcat $S 2$. The center of the area centralis, a region is which total ganglion cell densities in wildcat are above $10,000 / \mathrm{mm}^{2}$ and in which cone densities are elevated, is encircled. The region reproduced in Figure $6 \mathrm{D}$ is outlined by the solid-line rectangle. Comparable data for alpha cell density in central retina of the domestic cat are provided in Figure $8 A$ of Wässle et al. (1975).

in wildcats than in domestic cats: $260,000 \pm 6300$ in $S 1$ and $234,000 \pm 4500$ in $S 2$ versus 150,000-165,000 in domestic cats (Chalupa et al., 1984; Williams et al., 1986). This difference between species is significant $(t=6.7, p<0.05$, two-tailed test; domestic cat data taken from Chalupa et al., 1984; Williams et al., 1986).

\section{Axon populations in the nerves of the fetal wildcat}

Gestation in the wildcat is of the same duration as that of the domestic cat $(63 \pm 3 \mathrm{~d})$; weight at birth is about the same, as is the age at eye opening (Lindemann and Rieck, 1953; Hemmer, 1976; Rodríguez de la Fuente, 1979). We therefore estimated the age of the fetal wildcat using data on the tempo of development in the domestic cat (Williams and Chalupa, 1982; Shatz, 1983; Williams et al., 1986). On the basis of parameters such as crown-to-rump length, body weight, eye mass, and retinal surface area, we conclude that the developmental stage of this wildcat fetus corresponds very closely to that of fetal domestic cats between embryonic day 38 (E38) and E40 (Table 2).

The density of axons in the fetal wildcat nerves is extremely

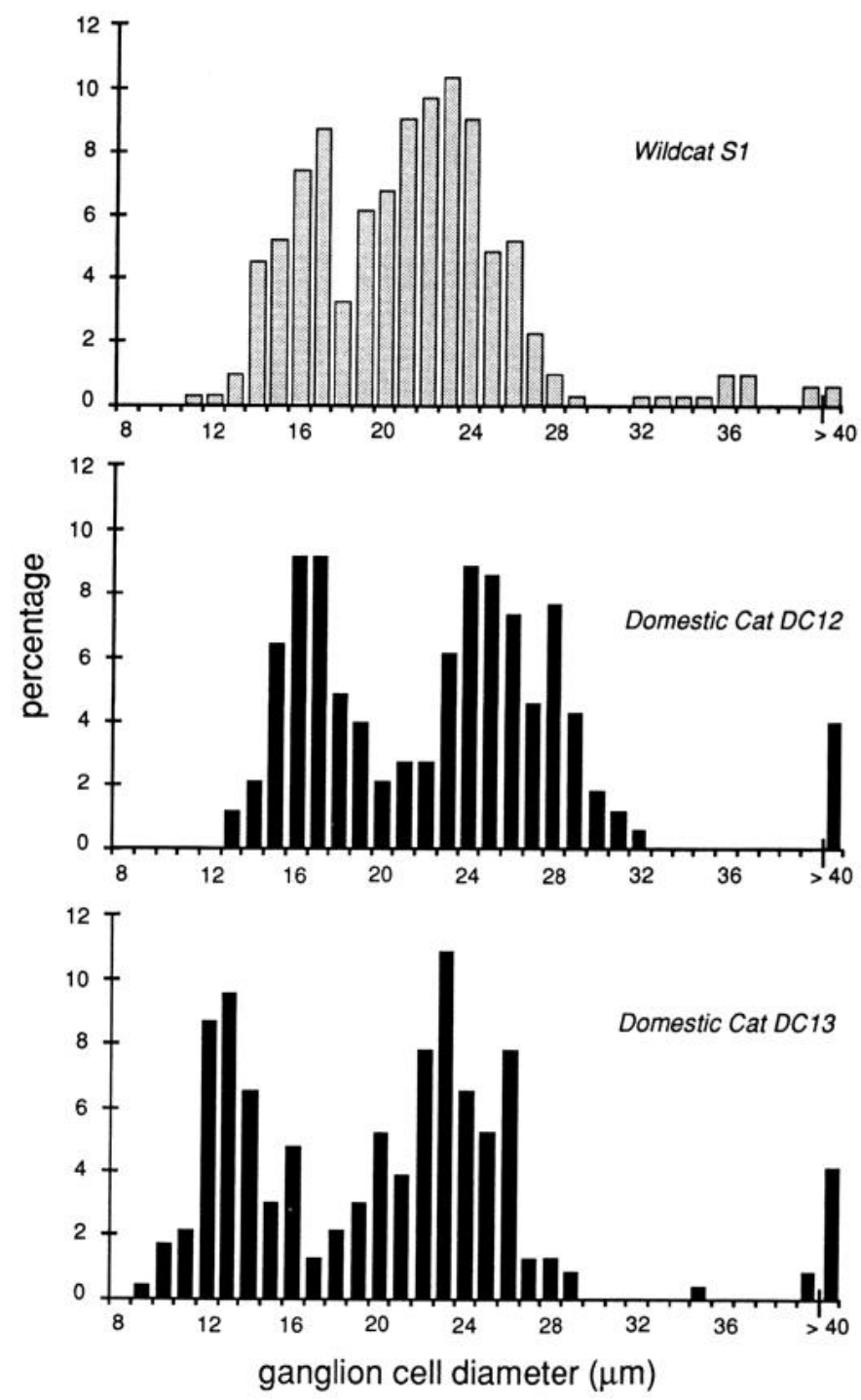

Figure 10. Ganglion cell size in a wildcat and two domestic cats at sites $9 \mathrm{~mm}$ above the area centralis in the nasal hemiretina. HRP-labeled cells were measured. Note the substantial variation in the two lower histograms taken from two domestic cats.

high - an average of $800 / 100 \mu \mathrm{m}^{2}$ (Fig. 13B). This is very close to the value of $735 / 100 \mu \mathrm{m}^{2}$ in the domestic cat fetus at E39. The right and left optic nerves of the wildcat fetus contain 670,000 $\pm 30,000$ and $540,000 \pm 30,000$ axons, respectively. The difference between right and left nerves is high and could be due to undercounting in the left nerve. However, there was no particular technical difficulty in counting either nerve, and it seems as likely that the difference reflects small variation in the tempo

Figure 11. On-center and off-center ganglion cells in the wildcat. $A$, Three off-center beta cells (arrowheads) have dendrites located in the inner plexiform layer in a focal plane $12 \mu \mathrm{m}$ away from the location of their cell body centers. $B$, Typical thin dendrites of two adjacent on-center beta cells located $5 \mu \mathrm{m}$ distant from the center of their cell bodies. $C$, A single field photographed at two focal planes in the inner plexiform layer. The upper half of the field is filled by the large dendrites of an off-center beta cell at a depth of $15 \mu \mathrm{m}$. The lower half shows part of the arbor of an oncenter beta cell at a depth of $8 \mu \mathrm{m}$. This field is located $2.5 \mathrm{~mm}$ dorsal to area centralis. $D$, Typical asymmetrical orientation of off-beta cell dendrites. Note the large caliber of the dendritic trunk. $E$, Large on-center alpha cell, six beta cells, and three gamma cells. The identity of each cell in this field is depicted schematically in Figure 7 at a location $9.3 \mathrm{~mm}$ dorsal to area centralis and $1.75 \mathrm{~mm}$ nasal to the decussation line. $\overline{7}$, Video image and drawing of an off-beta cell (see Fig. 12) viewed on the monitor using video overlay. The drawing of the cell has been offset slightly above the black-and-white image of the HRP-labeled cell. It is possible to plot large fields of cells at high magnification using this system. Magnification: $A, B, D$, and $E, 530 \times ; C, 1325 \times ; F, 800 \times(1600 \times$ on the monitor). 

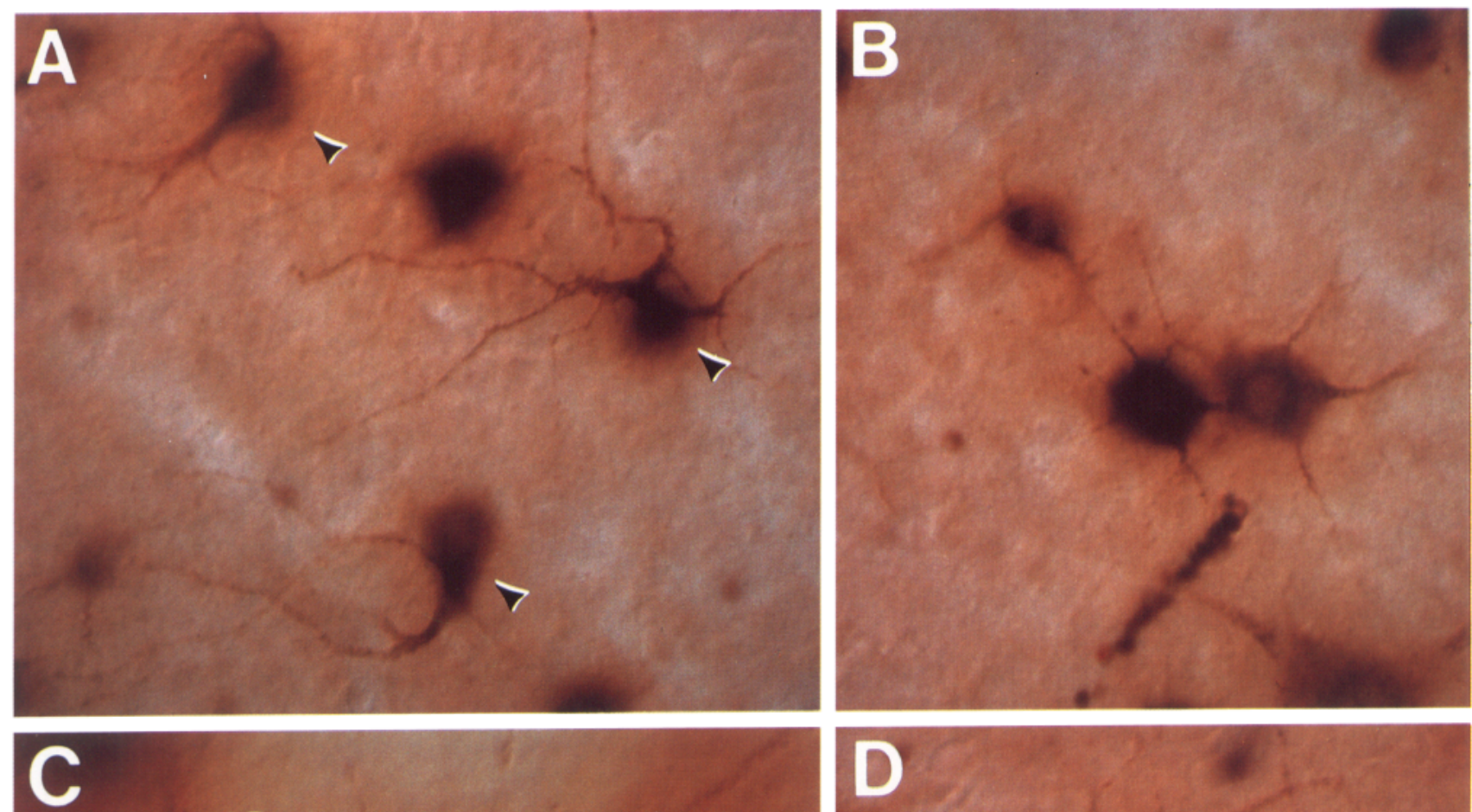

\section{5 rm}

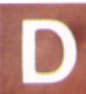

\section{$8 \mu \mathrm{m}$}
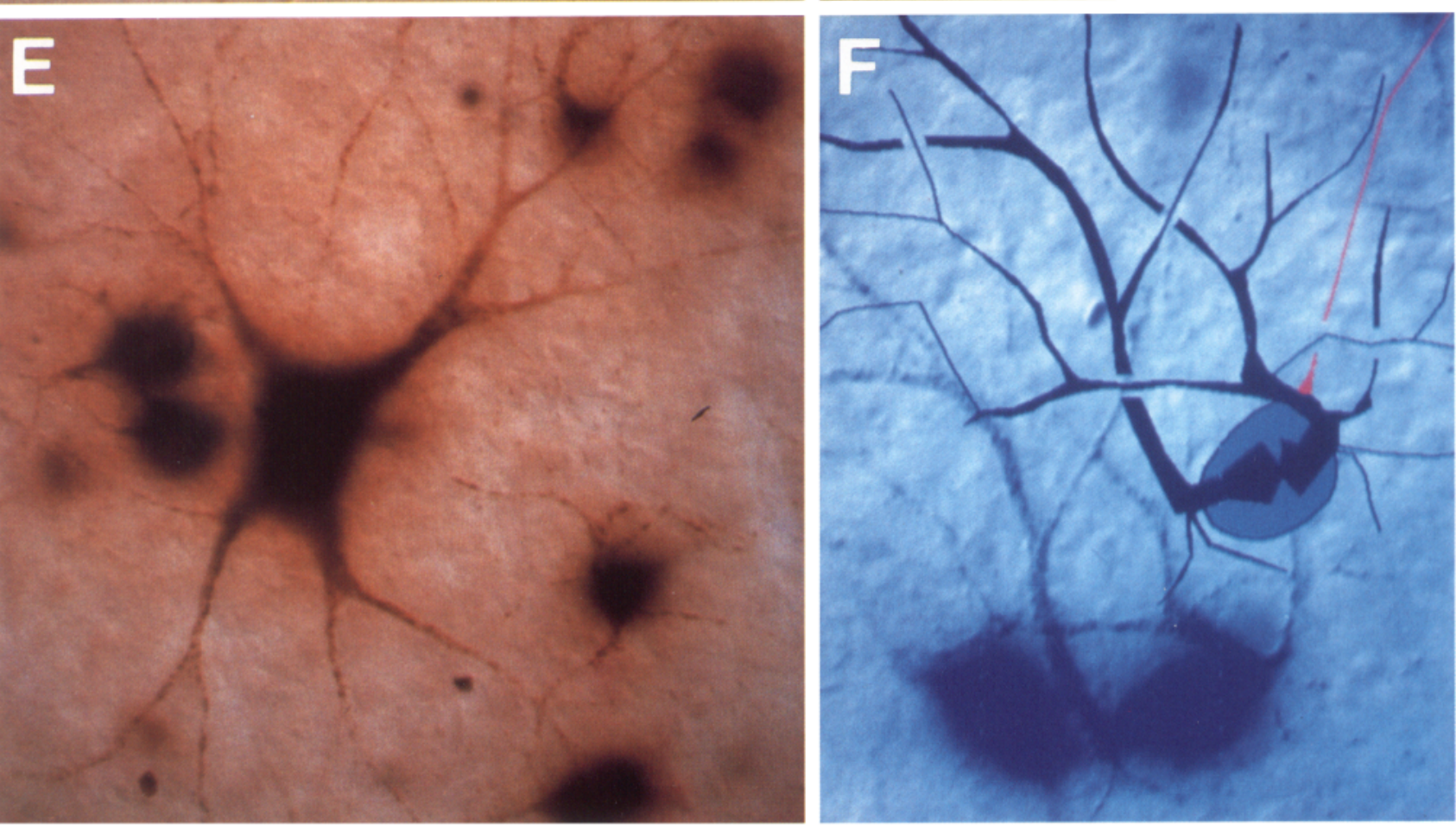

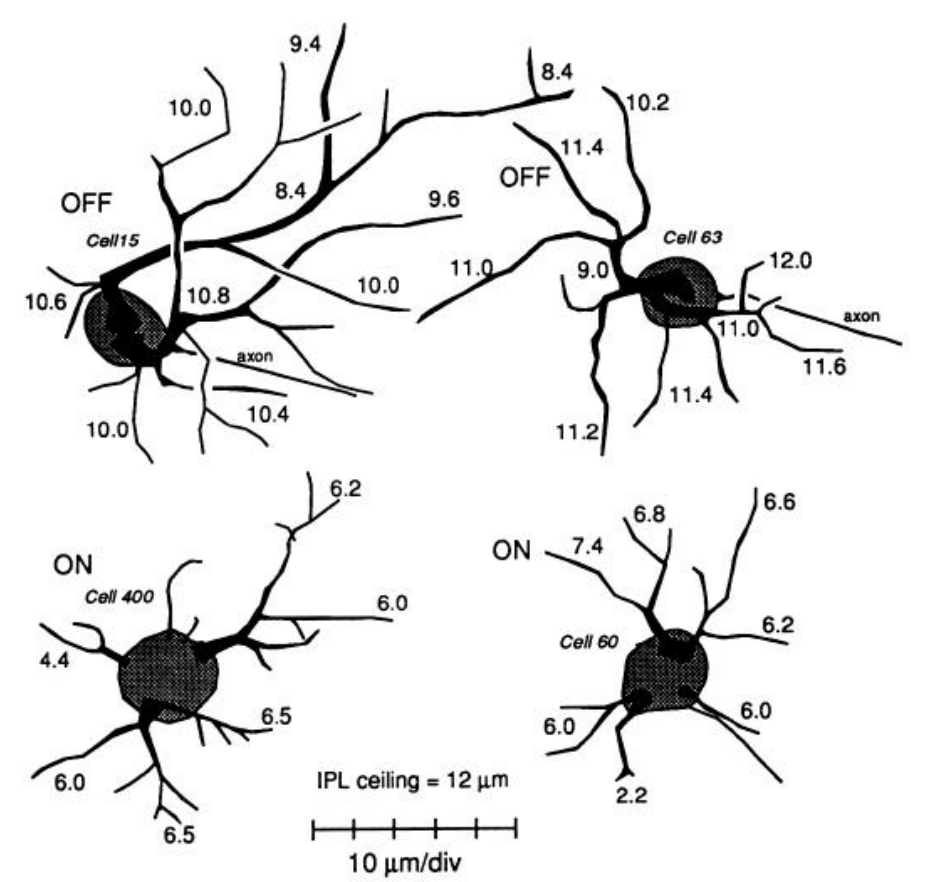

Figure 12. Typical morphology and dendritic depth of on- and offcenter beta cells in the inner plexiform layer of wildcat $S 1$. The depths of different dendritic segments were measured from the equator of the cell body. The interface of inner plexiform and inner nuclear layers was typically $12 \pm 1 \mu \mathrm{m}$ from the middle of the ganglion cell layer in the mid periphery of this retina. There is no appreciable overlap in the beta cells. A video-overlay image of the off-center beta cell in the upper left quadrant is shown in Figure $11 F . I P L$, inner plexiform layer.

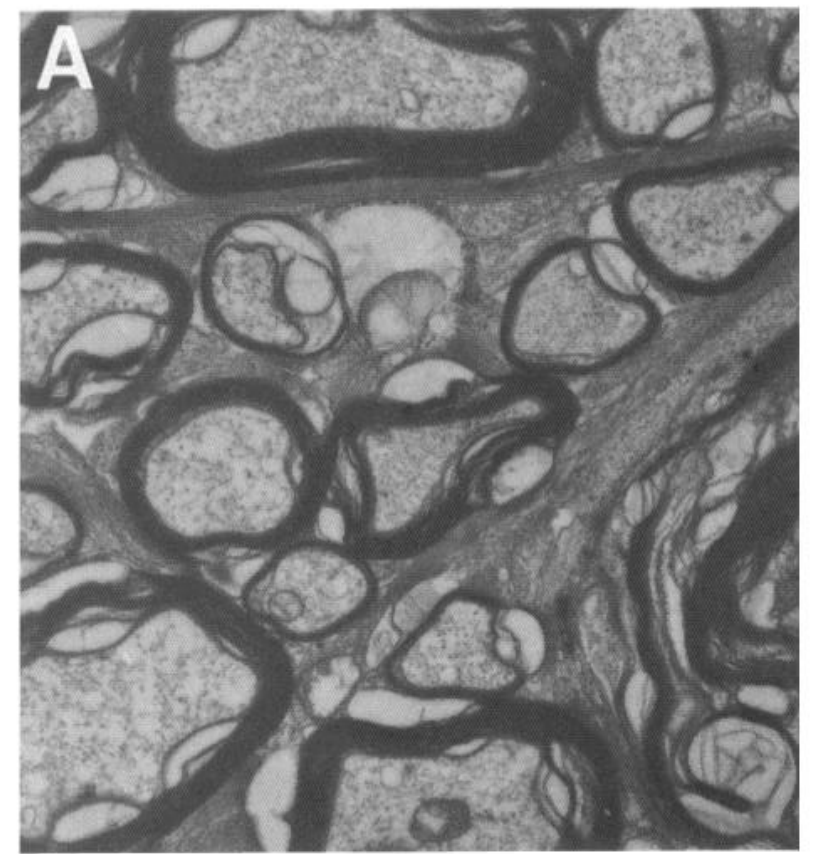
depth of secondary and tertiary dendritic branches of on- and off-center

Table 2. Comparison of fetal wildcat and fetal domestic cat

\begin{tabular}{lcc} 
& Fetal wildcat & $\begin{array}{c}\text { Domestic } \\
\text { cats, } \\
\text { E38/E39 }\end{array}$ \\
\hline Crown-rump length & $65 \mathrm{~mm}$ & $66-71 \mathrm{~mm}$ \\
Weight & $19.4 \mathrm{gm}$ & $20-22 \mathrm{gm}$ \\
Brain weight & $570 \mathrm{mg}$ & $560 \mathrm{mg}$ \\
Eye weight & $40 \mathrm{mg}$ & $35-48 \mathrm{mg}$ \\
Area of retinas & $30 \mathrm{~mm}^{2}$ & $20-25 \mathrm{~mm}^{2}$ \\
\hline
\end{tabular}

of development in the two eyes (see Williams et al., 1991). In any case, the estimates from this animal are remarkably close to those of two E39 domestic cat littermates we have previously studied $-698,000 \pm 20,000$ and $557,000 \pm 28,000$ (Williams et al., 1986). The percentages of growth cones and necrotic fibers in the wildcat fetal nerves are also very close to those found in domestic cats at E39 (Table 3). These two parameters are sensitive indicators of the rate of change in the fiber population during development. The low density of both growth cones and necrotic fibers (Table 3 ) indicates that the population of fibers counted in these fetal wildcat nerves is at or very close to the ontogenetic peak.

\section{Analysis of the dorsal lateral geniculate nucleus}

The volume of the LGN is less in domestic cat

The volume of the LGN calculated from both frozen and celloidin sections is substantially greater in the wildcat than in the domestic cat (Table 4). For example, the left LGN volume of domestic cat $D 1$ is $28.1 \mathrm{~mm}^{3}$, whereas corresponding values for the two series of frozen sections from the wildcats are 38.1 and

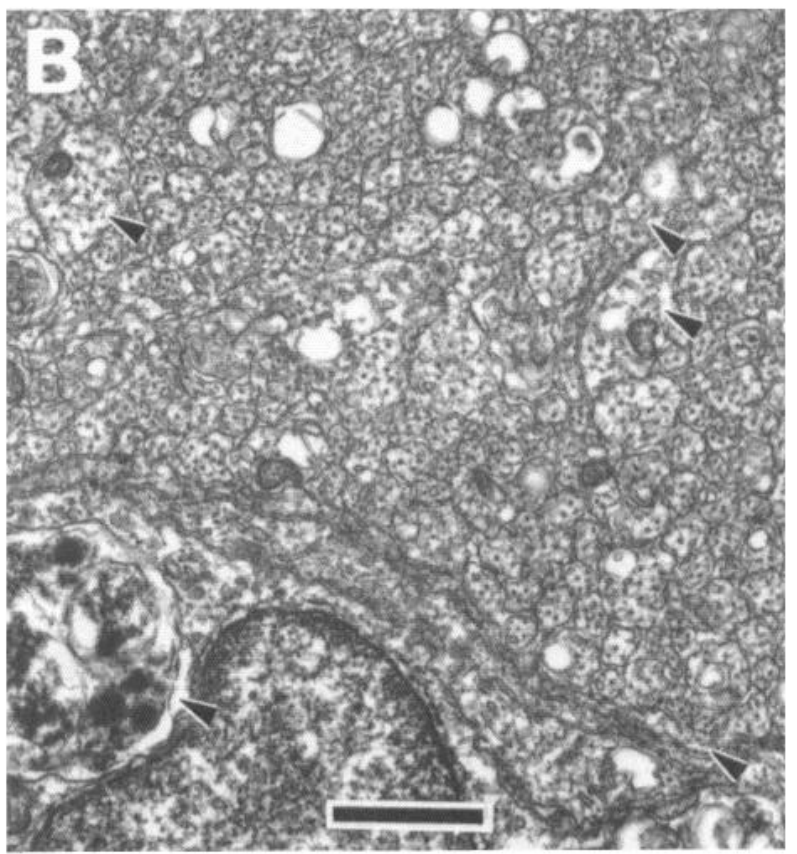

Figure 13. Electron micrographs of optic nerve fibers in wildcat. $A$, Micrograph of a field in the left nerve of $S 2$ at the same magnification $(11,000 \times)$ used to count axons. Due to substantial fiber and myelin distortion, fiber diameter was not measured. $B$, Fibers in the left optic nerve of a fetal wildcat. This micrograph is also reproduced at the magnification at which the analysis was performed $(15,000 \times)$. Arrowheads mark four growth cones and their shanks and, in the lower left, one large necrotic fiber. Comparable micrographs from a domestic cat fetus are reproduced in Figure 21 of Williams et al. (1986). Scale bar, $1 \mu \mathrm{m}$. 
Table 3. Analysis of optic axons in fetal wildcat and fetal domestic cats

\begin{tabular}{lcccc} 
& Fetal wildcat & & Domestic, E39 & Domestic, E39 $^{a}$ \\
\cline { 2 - 5 } & Left & Right & $557,000 \pm 28.000$ & $698,000 \pm 20,000$ \\
\hline Axon population & $536,000 \pm 29,000$ & $668,000 \pm 29,000$ & 74,400 & 75,700 \\
Area of nerve $\left(\mu \mathrm{m}^{2}\right)$ & 75,000 & 73,000 & 749 & 729 \\
Axon density $(100 \mu \mathrm{m})$ & 714 & 911 & 0.21 & 0.26 \\
Necrotic fibers $(\%)$ & 0.07 & 0.16 & 0.20 & 0.20 \\
Growth cones $(\%)$ & 0.17 & 0.15 & \\
\hline
\end{tabular}

" Data from E39 domestic cat littermates from Williams et al. (1986, their Table 1).

$35.5 \mathrm{~mm}^{3}$. After embedding the other hemisphere of the same domestic cat in celloidin, the LGN volume is reduced by processing to merely $10.4 \mathrm{~mm}^{3}$. Corresponding LGN volumes for the two wildcat hemispheres fixed, embedded, and cut in precisely the same manner are 17.9 and $18.9 \mathrm{~mm}^{3}$. A reasonable estimate based on our own material and that kindly lent us by Drs. Frost and Elberger (Table 4) is that the wildcat LGN has a volume that is roughly half again as large as that of the domestic cat LGN. The relative volumes of major components of the LGN are similar in domestic cats and wildcats (Table 4). In both species, the A layer occupies about $37 \%$ of the nucleus, whereas the Al layer occupies $28 \%$.

\section{Marked species differences in total neuron number}

As the foregoing analysis might lead one to suspect, the neuron population of the wildcat $L G N$ is much higher than that of the domestic cat LGN (Table 4, right column). The populations of LGN neurons in the two wildcats were 766,000 and 754,700 (averages of left and right nuclei for $S 1$ and $S 2$, respectively). In comparison, the average population in five domestic cats was only $510,000 \pm 26,000$. These estimates include interneurons and principal neurons, and our values for the domestic cat are extremely close to those calculated by Madarász et al. (1978; their estimate: 555,000 neurons). If we make the reasonable assumption that LGN cell populations are distributed normally in both species, then this species difference is highly significant $(t=15.34, p<0.05$, two-tailed test $)$.

Cell size in the $L G N$. Neurons in the two species are very closely matched in size. Sets of between 75 and 200 neurons were measured in layers $\Lambda, \Lambda 1$, and the $C$ layers, in two or three sections from each of six animals. We found no difference in cell size between domestic cats and the wildcats (Table 5). In both species, the smallest interneurons range in size from 50 to $80 \mu \mathrm{m}^{2}$, whereas principal neurons range from $90 \mu \mathrm{m}^{2}$ to more than $400 \mu \mathrm{m}^{2}$. Even a comparison of the size distribution in wildcat and domestic cat cases with large differences in LGN volume $\left(18.9 \mathrm{~mm}^{3}\right.$ vs. $\left.10.4 \mathrm{~mm}^{3}\right)$ demonstrates a remarkable similarity in the sizes of neurons in the two species (Fig. 14).

In comparison with the domestic cat, it does not appear that any particular layer differs either in volume or in cell number more or less than the nucleus as a whole (Table 4). It is of course possible that the relative abundance of classes of LGN neurons-particularly classes 1 and 2 of Guillery (1966)-differs between wildcat and domestic cat. Unfortunately, these cell classes cannot be distinguished as easily in the LGN as they can in the retina.

\section{Discussion}

\section{The descent of the domestic cat}

The species $F$. silvestris dates back to the middle Pleistocene (Holsteinian interglacial period; Kurtén, 1965b, 1971). During the late Pleistocene, the ancestral population of large wildcats gave way to the smaller European and North African wildcat subspecies, $F$. silvestris silvestris and $F$. silvestris lybica. These subspecies provided the stock from which domestic cats trace their descent over 3000 years ago (Zeuner, 1963; Wayne et al., 1989). Although details of this phylogenetic reconstruction may be modified as more material is recovered, there can be little doubt that among extant wildcats, the Spanish subspecies is morphologically closest to the Pleistocene stem population.

Dwarfing. There have been at least two distinct episodes of

Table 4. LGN volume and neuron populations

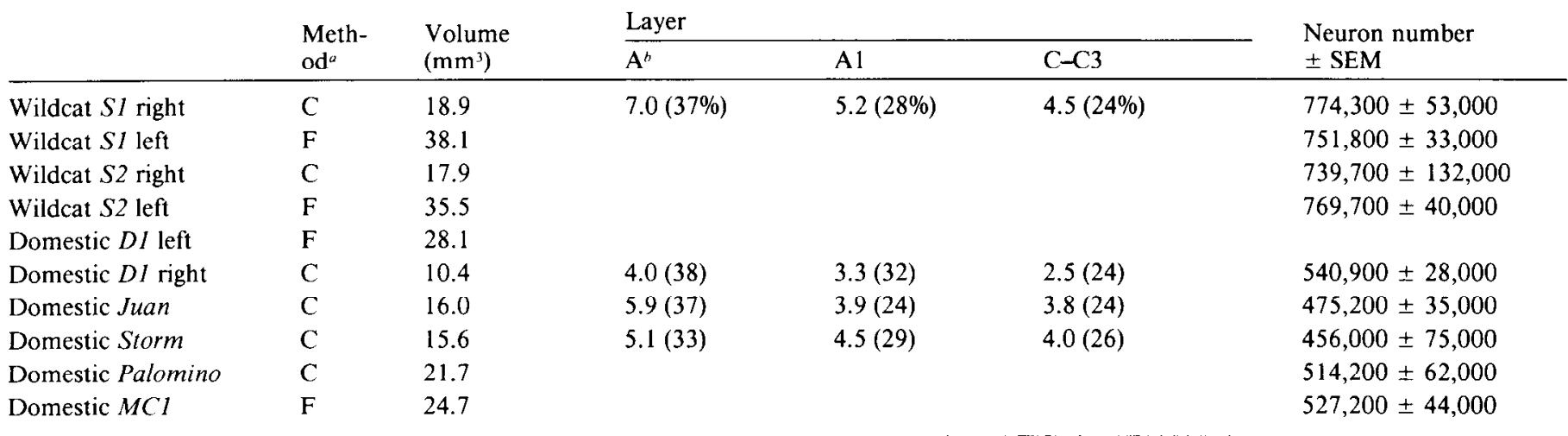

" $\mathrm{C}$, celloidin-embedded material; $\mathrm{F}$, ritaterial cut frozen.

The percentage contribution of each layer to the total LGN volume is provided in parentheses. 
Table 5. LGN neuron size

\begin{tabular}{llll} 
& \multicolumn{2}{l}{ Layer } \\
\cline { 2 - 4 } & A & A1 & C-C3 \\
\hline Wildcat $S 1$ & 168 & 170 & 126 \\
Wildcat $S 2$ & 134 & 143 & 131 \\
Domestic DI & 166 & 160 & 103 \\
Domestic Juan & 174 & 184 & 164 \\
Domestic Palomino & 164 & 170 & 144 \\
Domestic $M C 1$ & 153 & 159 & 100
\end{tabular}

Cross-sectional areas $\left(\mu \mathrm{m}^{2}\right)$ were measured at the focal plane in which this value reaches a maximum. The SEM for each value is between 3 and $9 \mu \mathrm{m}^{2}$. All material, except that from case $M C I$, was embedded in celloidin. In case $M C 1$, the brain was cut frozen. There is a surprising degree of variation among the mean size of cells in the $C$ layers of domestic cats (range, 100-164). This variation appears to be independent of cell size in the magnocellular layers.

selection in the lineage that has led to the domestic cat. The first episode has been associated with a rapid decline in body size. This reduction occurred at the close of the Pleistocene, long before domestication (Kurtén, 1965a,b; Table 1). Such dwarfing is by no means exceptional; extremely rapid reduction in body size has been widespread among the Pleistocene mammalian fauna of Eurasia, North America, and Australia (Kurtén, 1959; Marschall and Corrunccini, 1978; Stanley, 1979; Raff and Kaufman, 1983). With the exception of the Spanish wildcat subspecies, the reduction in body size in the $F$. silvestris lineage has proceeded at a particularly rapid rate-about 30 darwins over the last 20,000 years (Kurtén, 1958, 1959, 1965b, his Fig. 10; one darwin is equivalent to an $e$-fold change over 1 million years). On the basis of our data, and conforming to allometric tendencies, the tempo of change in the visual system appears to have proceeded at a reduced, but still very rapid rate (about 15 darwins). As in other lineages, the reduction may have been linked with postglacial climatic change and human competition (Kurtén, 1965a, 1988; Van Valen, 1969; Martin and Klein, 1984).

Domestication. The second episode of intense selection has been associated with domestication. This process has undoubtedly caused changes in brain, behavior, and reproduction (Darwin, 1890; Zeuner, 1963). However, the effects of domestication on brain structure have not yet been studied in detail (but see the exceptional work of Menner, 1939; Röhrs, 1955; Ebinger and Lohmer, 1987). One problem facing this type of analysis is that changes in brain structure associated with altered body size must be dissociated from those effects due only to domestication. In our cellular analysis of retina and LGN of cats, we have also been unable to dissociate these effects. Although we have shown that the difference in average body size of the Spanish wildcat subspecies and the domestic cat is sufficient to account for the overall reduction in brain mass in the domestic lineage (see Results), it is probable that specific selective pressures, particularly those associated with cohabitation with humans, have also generated specific changes in brain structure. A comprehensive comparative analysis of other components of the CNS and of different wildcat subspecies would be particularly useful in sorting the relative importance of size reduction and domestication in driving brain evolution. It would be especially interesting to study the brain of the smaller North African wildcat, F. silvestris lybica.

\section{Brain to body size scaling: a cellular analysis of allometry}

In this study we have focused on quantitative evolutionary changes within a small part of the CNS. Our data provide a cellular perspective on allometric change in the size of the brain and body. This cellular level of analysis complements previous work on brain-body allometry, which has generally focused on such global factors as ecological niche, taxonomic level, metabolic load, and developmental timing (Eisenberg and Wilson, 1978; Lande, 1979; Armstrong, 1982; Martin and Harvey, 1985, asscsscd in Mann et al., 1988; Preuss, 1992).

The average size difference between the Spanish wildcat and domestic cat is approximately twofold $-6-7 \mathrm{~kg}$ for the wildcat versus $2.5-3.5 \mathrm{~kg}$ for the domestic cat. The $25-30 \%$ difference in average brain weight $-31-37 \mathrm{gm}$ for the wildcats versus $25-$ $29 \mathrm{gm}$ for the domestic cat-is almost precisely what one would predict from the allometric relationship calculated for felids (Davis, 1962). We note that the two wildcats we studied weighed less than is typical, presumably due to their prolonged captivity. However, this does not compromise our observation that their brains are much larger than those of domestic cats, and that the weights of their brains are consistent with allometric predictions based on the average body weight of the Spanish wildcat.

We can now ask and answer more interesting questions: how
Figure 14. Size distribution of neuronal cell bodies in the LGN of wildcat $S 1$, and a domestic cat. In both cases, 1000 cells were measured in sample regions extending through all laminae. We used celloidin-embedded tissue for this analysis. These areal measurements of cell size greatly underestimate the in vivo values due to tissue shrinkage (Weber and Kalil, 1983).

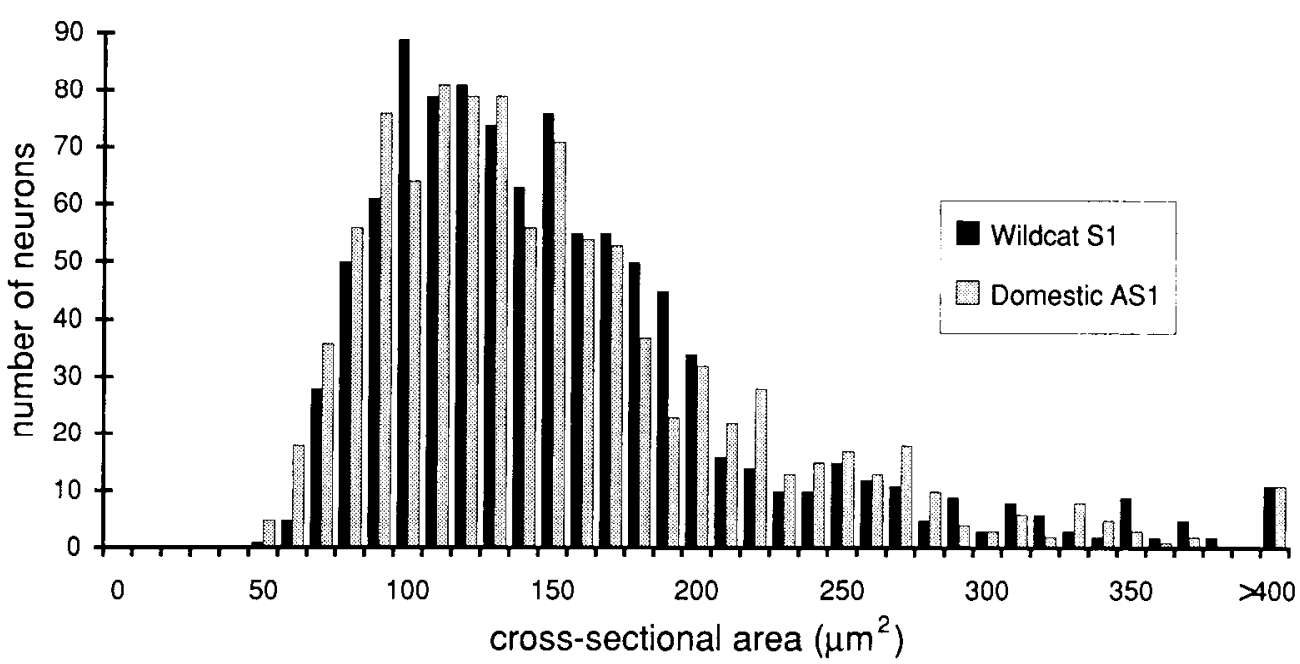


has the allometric reduction in brain weight in the cat lineage been accomplished? What are the cellular correlates or mechanisms? Our results reveal that in the primary visual system, the decrease in brain mass has been brought about strictly by reductions in cell number. In particular, we have shown that populations of retinal ganglion cells and neurons in the LGN are reduced $30-35 \%$. This reduction matches the reduction in total brain weight. There is no evidence for any change in neuron size or in the amount of neuropil. If one is willing to generalize our findings in retina and the LGN to the entire CNS, then it follows that the total population of neurons is about $30 \%$ less in the domestic cat than in the wildcat.

These data suggest that rapid evolutionary modulation in brain size is brought about primarily by changes in cell number. Wikler et al. (1989) have also noted that the cvolution of the retina in the Cricetidae family has primarily involved change in cell number. In contrast, long-term brain evolution encompassing many millions of years of divergence has often been associated with substantial changes in cell type and cell size, dendritic and electrophysiological properties, and the number of cytoarchitectonic areas (Holloway, 1968; Purves et al., 1986; Kaas, 1987; Purves, 1988; Bekker and Stevens, 1990; Reiner, 1991). Such changes must usually involve more far-reaching genetic and epigenetic reprogramming than those associated with fluctuations in cell number alone.

Allometric exceptions. We found several interesting exceptions in which numbers of cells appear not to have changed as one would predict from the allometric relationship between brain and body size. First, the population of rods in the domestic cat equals, and may even exceed, that in the wildcat. Rod densities in the arca centralis and along part of the horizontal axis in domestic cats (Steinberg et al., 1973; present results) are higher than those measured in the male wildcat $S 1$. Although it would be unwise to read too much into this difference, given the variability in rod and cone densities in other species (Curcio et al., 1990; Wikler et al., 1990; Williams, 1991), we can certainly say that the rod population is as high (and possibly higher) in the donestic cat as in the Spanish wildcat. Similarly, the population of alpha ganglion cells in the domestic cat has not undergone any reduction. In fact, densities of alpha cells at the center of the area centralis may be slightly higher in domestic cats than in the wildcat retinas that we studied. This evolutionary stasis in alpha cell number stands in marked contrast to the sharp decline in the total ganglion cell population.

These two intriguing exceptions demonstrate that allometric changes in brain mass represent averages that can mask substantial variation in the magnitude of change among different neuron subpopulations (Harvey and Krebs, 1990). As we and others have shown, these differential effects on neuron populations may be prominent even when the evolutionary and genetic separation between two species, or even two strains, is exceedingly small (Smith, 1928; Holloway, 1968; Wimer et al., 1976; Ebinger and Lohmer, 1987). In the domestic cat lineage, selective pressures appear to have counterbalanced allometric tendencies and thereby have maintained scotopic and motion sensitivity by leaving intact genetic and epigenetic mechanisms responsible for generating and maintaining populations of rods and alpha ganglion cells. In contrast, populations of cones and beta ganglion cells (particularly in the area centralis) have not been spared a sharp decline. Cellular selectivity of this sort serves to emphasize the underlying genetic and epigenetic complexity of allometric relations.

\section{A subtle difference between on-and off-center beta cell dendrites is conserved in both Felis species}

We initially thought that the marked dendritic differences noted between on- and off-center beta cells (symmetric vs. asymmetric and thick vs. thin primary dendrites) were unique to the wildcat (Figs. 11, 12)-that we had finally detected a significant qualitative difference. However, careful inspection of domestic cat retinas revealed precisely the same structural differences between on- and off-center beta cells. Although we are the first to comment on this dichotomy between on- and off-center beta cells, some of these differences can be discerned in figures of previous reports on domestic cat ganglion cells (e.g., Wässle et al., 1981b; Rowe and Dreher, 1982; Stanford, 1987). These marked structural differences in dendrites suggest that a functional reanalysis such as that of Koch et al. (1982) would be revealing, and that these two subtypes of neurons may have unsuspected electrotonic differences. From an evolutionary perspective, it is also noteworthy that relatively subtle, previously undetected, dendritic differences have been conserved in this lineage despite large differences in numbers of these cells. An analysis of on- and off-center cells in other mammals would be of interest to assess the taxonomic breadth of this dichotomy.

\section{Developmental mechanisms and brain evolution}

An intriguing question is raised by these findings: at what stage of development and in what manner do the great differences between the brains of wild and domestic species arise? As mentioned in Results, the length of gestation in wild and domestic cats is about the same (63 d), birth weight is roughly the same $(100 \pm 20 \mathrm{gm})$, and eye opening occurs at the same age (7-10 $\mathrm{d}$ after birth). One explanation for the reduction in the size of the domestic cat's brain is that far fewer neurons are generated early in development. A more counterintuitive, but equally possible, alternative is that the same numbers of neurons are generated in the domestic cat as in the wildcat, but that many more of these cells are subsequently eliminated. For reasons listed below, we think that the decreasc in brain sizc in the domestic lineage is probably associated with an increase in the incidence of cell death.

Cell death in the domestic cat retina is particularly severe$80 \%$ of all ganglion cells die in prenatal and early postnatal development (Williams et al., 1986). This magnitude of cell death exceeds by a wide margin that in other vertebrates in which ganglion cell death has yet been studied, including rhesus macaque and human (Rakic and Riley, 1983; Provis et al., 1985). As suggested in previous work (Williams et al., 1986), the excessive production of ganglion cells in the domestic cat fetus may be an ontogenetic trait held over from its large wildcat ancestor-a form of phylogenetic inertia (Harvey and Purvis, 1991). The elimination of this surplus may correspond to what Glücksmann (1951) has referred to as phylogenetic cell death. Our remarkable but admittedly tentative finding that the numbers of optic axons in wildcat and domestic cat fetuses do not differ appreciably early in development is consistent with a role for ganglion cell death operating at a later stage of development in generating the marked species differences seen at maturity.

The idea that brain evolution may be associated with late fetal and early neonatal modulation in the incidence of cell death is also consistent with an observation first made by von Baer (1828) that early stages of development in related species tend to be relatively uniform whereas late stages tend to differ (Gould, 
1977; Buss, 1987). A developmental and evolutionary shift in the onset or duration of cell death in a lineage may be just as effective in changing CNS structure as a heterochronic shift in the onset or duration of cell proliferation (Goldowitz, 1989; Wikler and Finlay, 1989). Of course, the modulation of cell death is ultimately limited by the degree of neuron overproduction. Consequently this mechanism cannot provide an explanation for the long-term phyletic increase in brain size that is prominent in some mammalian lineages. For instance, it is improbable that the brain of Homo sapiens is larger than that of its Australopithecine ancestors simply because fewer neurons are lost at a late stage of development.

Our argument implies that the severity of cell death is generally elevated in the CNS of domestic cats in comparison to that in the CNS of Spanish wildcats-a testable prediction. It may be the case that large litter size and the high metabolic load of late pregnancy on smaller domestic females serve as a biochemical brake that eliminates many neurons when they first become active. This metabolic interpretation provides some rationale for the loss of normally connected neurons (Williams and Herrup, 1988; Chalupa and Lia, 1991; Oppenheim, 1991).

The modulation of rates of cell death rather than of rates of cell production could be of selective advantage in making possible rapid and well-matched evolutionary changes in the size of interconnected neuron populations (Katz and Lasek, 1978; Finlay et al., 1987). Seen in this light, the overproduction of neurons in a species represents a concealed source of variation that can be easily exploited in response to selective pressure by a simple change in the incidence of cell death (Williams and Herrup, 1988). There is a great deal of evidence that the modulation of cell death is in large part governed by highly flexible trophic feedback mechanisms (Purves, 1988). Such responsive and contingent mechanisms may effectively loosen the grip of epigenetic constraints on brain evolution (Katz and Lasek, 1978; Hamburger and Oppenheim, 1982). These ideas are compatible with the neatly matched $30 \%$ difference in both retinal ganglion cell and LGN neuron populations that we have documented in this study.

Modes of development are subject to selection both at the level of the individual and at the level of the species. The presence or absence within a lineage of a mechanism involving the overproduction and subsequent loss of neurons via trophic interactions may provide a concrete developmental basis for differences in rates of speciation (Purves, 1988) and, consequently, for selection at, or even above, the species level (Stanley, 1975; Raff and Kaufman, 1983; Vrba, 1983).

\section{References}

Armstrong E (1982) Relative brain size and metabolism in mammals. Science 220:1302-1304.

Bekker JM, Stevens CF (1990) Two different ways evolution makes neurons larger. Prog Brain Res 83:37-45.

Benveniste RE (1985) The contributions of retroviruses to the study of mammalian evolution. In: Molecular evolutionary genetics (MacIntyre RJ, ed), pp 359-417. New York: Plenum.

Boycott BB, Wässle H (1974) The morphological types of ganglion cells of the domestic cat's retina. J Physiol (Lond) 240:397-419.

Brandgaard H, Gundersen HJG (1986) The impact of recent stereological advances on quantitative studies of the nervous system. $J$ Neurosci Methods 18:39-78.

Buss LW (1987) The evolution of individuality. Princeton: Princeton UP.

Carroll RL (1988) Vertebrate paleontology and evolution. New York: Freeman.
Chalupa LM, Lia B (1991) The nasotemporal division of retinal ganglion cells with crossed and uncrossed projections in the fetal rhesus monkey. J Neurosci 11:191-202.

Chalupa LM, Williams RW, Henderson Z (1984) Binocular interaction in the fetal cat regulates the size of the ganglion cell population. Neuroscience 12:1139-1146.

CITES (1991) Convention on international trade in cndangercd species of wild flora and fauna, appendices I-III. Endangered species convention, Oct. 1, 1991, 50 CFR 23.23; Endangered and threatened wildlife and plants, July 15, 1991, 50 CFR 17.11.

Collier G, O'Brien SJ (1985) A molecular phylogeny of the Felidae: immunological distance. Evolution 39:473-487.

Cooper ML, Pettigrew JD (1979) The decussation of the retinothalamic pathway in the cat, with a note on the major meridians of the cat's eye. J Comp Neurol 187:285-312.

Clutton-Brock J (1981) Domesticated animals from early times. Cambridge: Cambridge UP.

Curcio CA, Sloan KR, Kalina RE, Hendrickson AE (1990) Human photoreceptor topography. J Comp Neurol 292:497-523.

Darwin C (1890) The variation of animals and plants under domestication, $2 \mathrm{~d}$ ed, rev. New York: Appleton.

Davis DD (1962) Allometric relationships in lions vs. domestic cats. Evolution 16:505-514.

Ebinger P, Lohmer R (1987) A volumetric comparison of brains between greylag geese (Anser anser L.) and domestic geese. J Hirnforsch 28:291-299.

Edinger T (1948) Evolution of the horse brain. Geol Soc Am Mem 25:1-177.

Edinger T (1966) Brains from 40 million years of Camelid history. In: Evolution of the forebrain (Hassler R, Stephan H, eds), pp 153161. Stuttgart: Thieme.

Eisenberg JF (1981) The mammalian radiation. An analysis of trends in evolution, adaptation, and behavior. Chicago: University of Chicago.

Eisenberg JF, Wilson DE (1978) Relative brain size and fecding strategies in the Chiroptera. Evolution 32:740-751.

Eldredge N, Gould SJ (1972) Punctuated equilibria: an alternative to phyletic gradualism. In: Models in paleobiology (Schopf TJM, ed), pp 82-115. San Francisco: Freeman, Cooper.

Finlay BL, Wikler KC, Sengelaub DR (1987) Regressive events in brain development and scenarios for vertebrate brain evolution. Brain Behav Evol 30:102-117.

Glücksmann A (1951) Cell deaths in normal vertebrate ontogeny. Biol Rev 26:59-86.

Goldowitz D (1989) Cell allocation in mammalian CNS formation: evidence from murine interspecies aggregation chimeras. Neuron 3: 705-713.

Gould SJ (1977) Ontogeny and phylogeny. Cambridge, MA: Harvard UP.

Gould SJ, Eldredge N (1986) Punctuated equilibrium at the third stage. Syst Zool 35:143-148.

Guillery RW (1966) A study of Golgi preparations from the dorsal lateral geniculate nucleus of the adult cat. J Comp Neurol 128:2150.

Haltenorth T (1953) Die Wildkatzen der Alten Welt. Eine Übersicht über die Untergattung Felis. Leipzig: Akademische Verlagsgesellschaft, Geest and Portig.

Hamburger V, Oppenheim RW (1982) Naturally occurring neuronal death in vertebrates. Neurosci Comm 1:39-55.

Harvey PH, Krebs JR (1990) Comparing brains. Science 249:139146.

Harvey PH, Purvis A (1991) Comparative methods for explaining adaptations. Nature 351:619-624.

Hemmer H (1976) Gestation period and postnatal development in felids. In: The world's cats, Vol 3, No 2 (Eaton RL, ed), pp 90-100. Seattle: Carnivore Research Institute, Burke Museum, University of Washington.

Holloway RL (1968) The evolution of the primate brain: some aspects of quantitative relations. Brain Res 7:121-172.

Hughes A (1975) A quantitative analysis of the cat retinal ganglion cell topography. J Comp Neurol 163:107-128.

Jacobs DS, Perry VH, Hawken MJ (1984) The postnatal reduction of the uncrossed projection from the nasal retina in the cat. J Neurosci $4: 2425-2433$. 
Jerison H (1979) Brain, body and encephalization in early primates. J Hum Evol 8:615-635.

Jerison HJ (1973) Evolution of the brain and intelligence. New York: $\Lambda$ cademic.

Kaas JH (1987) The organization and evolution of neocortex. In: Higher brain function: recent explorations of the brain's emergent properties (Wise SP, ed), pp 347-378. New York: Wiley.

Katz MJ, Lasek RJ (1978) Evolution of the nervous system: role of ontogenetic mechanisms in the evolution of matching populations. Proc Natl Acad Sci USA 75:1349-1352.

Kirby MA, Chalupa LM (1986) Retinal crowding alters the morphology of alpha ganglion cells. J Comp Neurol 251:532-541.

Koch C, Poggio T, Torre V (1982) Retinal ganglion cells: a functional interpretation of dendritic morphology. Philos Trans $\mathrm{R}$ Soc Lond [Biol] 298:227-264.

Kurtén B (1954) Observations on allometry in mammalian dentition: its interpretation and evolutionary significance. Acta Zool Fenn 76: $1-122$.

Kurtén B (1958) A differentiation index, and a new measure of evolutionary rates. Evolution 12:146-157.

Kurtén B (1959) Rates of evolution in fossil mammals. Cold Spring Harbor Symp Quant Biol 24:205-215.

Kurtén B (1965a) The Carnivora of the Palestine caves. Acta Zool Fenn 107:1-74.

Kurtén B (1965b) On the evolution of the European wild cat, Felis silvestris Schreber. Acta Zool Fenn 111:1-29.

Kurtén B (1971) The age of mammals. New York: Columbia UP

Kurtén B (1988) On evolution and fossil mammals. New York: Columbia UP

Lande R (1979) Quantitative genetic analysis of multivariate evolution applied to brain : body size allometry. Evolution 33:402-416.

Latimer HB (1938) The weights of the brain and of its parts, of the spinal cord and of the eyeballs in the adult cat. J Comp Neurol 68: $395-404$.

Lia B, Williams RW, Chalupa LM (1986) Does axonal branching contribute to the overproduction of optic nerve fibers during early development of the cat's visual system. Dev Brain Res 25:296-301.

Lindemann W, Rieck W (1953) Beobachtungen bei der Aufzucht von Wildkatzen. Z Tierpsychol 10:92-119.

Madarász M, Gerle J, Hajdu F, Somogyi G, Tömböl T (1978) Quantitative histological studies on the lateral geniculate nucleus in the cat. II. Cell numbers and densities in several layers. J Hirnforsch 19: 159-164.

Mann MD, Glickman SE, Towe AL (1988) Brain/body relations among myomorph rodents. Brain Behav Evol 31:111-124.

Marschall LG, Corrunccini RS (1978) Variability, evolutionary rates, and allometry in dwarfing lineages. Paleobiology 4:101-119.

Martin PS, Klein RG, eds (1984) Quaternary extinctions: a prehistoric revolution. Tucson: University of Arizona.

Martin RD, Harvey PH (1985) Brain size allometry. Ontogeny and phylogeny. In: Size and scaling in primate biology (Jungers WL, ed), pp 147-173. New York: Plenum.

Menner E (1939) Vergleichende Untersuchungen über die Retina wildlebender und domestizierter Caniden. Z Naturwiss Med Grundlagenforsch 93:77-88.

Mountcastle VB (1980) Medical physiology, 14th ed. St. Louis: Mosby.

Nikara T, Bishop PO, Pettigrew ID (1968) Analysis of retinal correspondence by studying receptive fields of binocular single units in the cat striate cortex. Exp Brain Res 6:353-372.

Oppenheim RW (1991) Cell death during development of the nervous system. Annu Rev Neurosci 14:453-501.

Otsuka R, Hassler R (1962) Über Aufbau und Gliederung der corticalen Sehsphäre bei der Katze. Arch Psychiatr Z Nervenkr Ges Neurol Psychiatr 203:212-234.

Pagel MD, Harvey PH (1989) Taxonomic differences in the scaling of brain on body weight among mammals. Science 224:1589-1593.

Peichl L, Wässle H (1981) Morphological identification of on- and off-centre brisk transient $(\mathrm{Y})$ cells in the cat retina. Proc $\mathrm{R}$ Soc Lond [Biol] 212:139-156.

Perry VH, Linden R (1982) Evidence for dendritic competition in the developing retina. Nature 297:683-685.

Preuss TM (1993) The role of neurosciences in primate evolutionary biology: historical commentary and prospectus. In: Primates and their relatives in phylogenetic perspective (MacPhee RDE, ed). New York: Plenum, in press.
Provis IM, van Driel D, Billson FA, Russell P (1985) Human fetal optic nerve: overproduction and elimination of retinal axons during development. J Comp Neurol 238:92 101.

Purves D (1988) Body and brain. A trophic theory of neural connections. Cambridge, MA: Harvard UP.

Purves D, Rubin E, Snider WD, Lichtman J (1986) Relation of animal size to convergence, divergence, and neuronal number in peripheral sympathetic pathways. J Neurosci 6:158-163.

Radinsky LB (1973) Evolution of the canid brain. Brain Behav Evol 11:169-202.

Radinsky LB (1975) Evolution of the felid brain. Brain Behav Evol 11:214-254.

Radinsky LB (1981) Brain evolution in extinct South American ungulates. Brain Behav Evol 18:169-187.

Raff RA, Kaufman TC (1983) Embryos, genes, and evolution. The developmental-genetic basis of evolutionary change. New York: Macmillan.

Rakic P, Riley K (1983) Overproduction and elimination of retinal axons in the fetal rhesus monkey. Science 219:1441-1444.

Reiner A (1991) A comparison of neurotransmitter-specific and neuropeptide-specific neuronal cell types present in the dorsal cortex in turtles with those present in the isocortex in mammals: implications for the evolution of isocortex. Brain Behav Evol 38:53-91.

Reinoso-Suârez F (1961) Topographischer Hirnatlas der Katze für experimental-physiologische Untersuchungen. Darmstadt: E. Merck.

Rodriguez de la Fuente F (1979) El gato montés. In: Fauna ibérica y europea, Vol VI, Bosque caducifolio. Bosque de coníferas y taiga, pp 60-69. Barcelona: Salvat Editores.

Röhrs M (1955) Vergleichende Untersuchungen an Wild- und Hauskatzen. Zool Anz 155:53-69.

Rosen GD, Harry JD (1990) Brain volume estimation from serial section measurements: a comparison of methodologies. J Neurosci Methods 35:115-124.

Rowe MH, Dreher B (1982) Functional morphology of beta cells in the area centralis of the cat's retina: a model for the evolution of central retinal specializations. Brain Behav Evol 21:1-23.

Rowe MH, Stone J (1976) Properties of ganglion cells in the visual streak of the cat's retina. J Comp Neurol 167:99-126.

Schindewolf $\mathrm{OH}$ (1950) Grundfragen der Paläontologie. Stuttgart: Schwarzerbart.

Shatz CJ (1983) The prenatal development of the cat's retinogeniculate pathway. J Neurosci 3:482-499.

Smith LA (1928) A comparison of the number of nerve cells in the olfactory bulbs of domesticated albino and wild Norway rats. J Comp Neurol 45:483-499.

Stanford LR (1987) X-cells in the cat retina: relationships between the morphology and physiology of a class of cat retinal ganglion cells. J Neurophysiol 58:940-964.

Stanley SM (1975) A theory of evolution above the species level. Proc Natl Acad Sci USA 72:646-650.

Stanley SM (1979) Macroevolution. Pattern and process. San Francisco: Freeman.

Steinberg RH, Reid M, Lacy PL (1973) The distribution of rods and cones in the retina of the cat (Felis domesticus). J Comp Neurol 148: $229-248$.

Stone J (1978) The number and distribution of ganglion cells in the cat's retina. J Comp Neurol 180:753-772.

Stone J, Rapaport DH, Williams RW, Chalupa LM (1982) Uniformity of cell distribution in the ganglion cell layer of prenatal cat retina: Implications for mechanisms of retinal development. Dev Brain Res $2: 231-242$

Van Valen L (1969) Evolution of communities and late Pleistocene extinctions. In: Proceedings of the North American Paleontology Convention, Chicago, pp 469-485.

von Baer KE (1828) Über Entwickelungsgeschichte der Thiere. Beobachtung und Reflexion, Pt I. Königsberg: Gebrüdern Bornträger (available at Beineke Library, Yale University).

Vrba ES (1983) Macroevolutionary trends: new perspectives on the roles of adaptation and incidental effect. Science 221:387-389.

Wässle H, Riemann RJ (1978) The mosaic of nerve cells in the mammalian retina. Proc $\mathrm{R}$ Soc Lond [Biol] 200:441-461.

Wässle H, Levick WR, Cleland BG (1975) The distribution of the alpha type of ganglion cells in the cat's retina. J Comp Neurol 159: $419-438$.

Wässle H, Peichl L, Boycott BB (1981a) Morphology and topography 
of on- and off-alpha cells in the cat retina. Proc R Soc Lond [Biol] 212:157-175.

Wässle H, Boycott BB, Peichl L (1981b) Morphology and mosaic of on- and off-beta cells in the cat retina and some functional considerations. Proc R Soc Lond [Biol] 212:177-195.

Wayne RK, Benveniste RE, Janczewski DN, O'Brien SJ (1989) Molecular and biochemical evolution of the Carnivora. In: Carnivore behavior, ecology, and evolution (Gittleman JL, ed), pp 465-494. Ithaca, NY: Cornell UP.

Weber AJ, Kalil RE (1983) The percentage of interneurons in the dorsal lateral geniculate nucleus of the cat and observations on several variables that affect the sensitivity of horseradish peroxidase as a retrograde marker. J Comp Neurol 220:336-346.

Wikler KC, Finlay BL (1989) Developmental heterochrony and the evolution of species differences in retinal specializations. In: Development of the vertebrate retina (Finlay BL, Sengelaub DR, eds), pp 227-246. New York: Plenum.

Wikler KC, Perez G, Finlay BL (1989) Duration of retinogenesis: its relationship to retinal organization in two Crisitine rodents. J Comp Neurol 285:157-176.

Wikler KC, Williams RW, Rakic P (1990) Photoreceptor mosaic: number and distribution of rods and cones in the rhesus monkey retina. J Comp Neurol 297:499-508.

Williams RW (1991) The human retina has a cone-enriched rim. Vis Neurosci 6:403-406.

Williams RW, Chalupa LM (1982) Prenatal development of the retinocollicular projections in the cat: an anterograde transport study. J Neurosci 2:604-622.

Williams RW, Chalupa LM (1983) An analysis of axon caliber within the optic nerve of the cat: evidence of size groupings and regional organization. J Neurosci 3:1554-1564.

Williams RW, Herrup K (1988) The control of neuron number. Annu Rev Ncurosci 11:423-453.

Williams RW, Rakic P (1988a) Elimination of neurons from the rhesus monkey's lateral geniculate nucleus during development. J Comp Neurol 272:424-436.

Williams RW, Rakic P (1988b) Three-dimensional counting: an accurate and direct method to estimate numbers of cells in sectioned material. J Comp Neurol 278:344-352.

Williams RW, Bastiani MJ, Chalupa LM (1983) Loss of axons in the cat optic nerve following fetal unilateral enucleation: an electron microscopic analysis. J Neurosci 3:135-146.

Williams RW, Bastiani MJ, Lia B, Chalupa LM (1986) Growth cones, dying axons, and developmental fluctuations in the fiber population of the cat's optic nerve. J Comp Neurol 246:32-69.

Williams RW, Borodkin M, Rakic P (1991) Growth cone distribution patterns in the optic nerve of fetal monkcys: implications for mechanisms of axon guidance. J Neurosci 11:1081-1094.

Wimer RE, Wimer CC, Vaughn JE, Barber RP, Balvanz BA, Chernow CR (1976) The genetic organization of neuron number in Ammon's horns of house mice. Brain Res 118:219-243.

Wong ROL, Hughes A (1987a) The morphology, number, and distribution of a large population of confirmed displaced amacrine cells in the adult cat retina. J Comp Neurol 255:159-177.

Wong ROL, Hughes A (1987b) Developing neuronal populations of the cat retinal ganglion cell layer. J Comp Neurol 262:473-495.

Zeuner FE (1963) A history of domesticated animals. New York: Harper and Row. 